\title{
The geology and hydrogeology of springs on Cape Breton Island, Nova Scotia, Canada: an overview
}

\author{
Fred E. BaechleR ${ }^{1}$, Heather J. Cross ${ }^{2}$, And Lynn BaechleR ${ }^{3}$ \\ 1. EXP Services Inc., 301 Alexandra Street, Suite A. Sydney, Nova Scotia B1S 2E8, Canada. \\ 2. Dartmouth, Nova Scotia B2W 3S6, Canada \\ 3. 92 Crestdale Drive, Sydney Forks, Nova Scotia B1P 6R7, Canada \\ *Corresponding Author: fred.baechler@exp.com
}

Date received: 10 July 2018 Date accepted: 29 January 2019

\begin{abstract}
Cape Breton Island springs have historically played a role in developing potable water supplies, enhancing salmonid streams, creating thin-skinned debris flows, as well as mineral and hydrocarbon exploration. Cape Breton Island provides a hydrogeological view into the roots of an ancient mountain range, now exhumed, deglaciated and tectonically inactive. Exhumation and glaciation over approximately $140 \mathrm{Ma}$ since the Cretaceous are of particular relevance to spring formation. A total of 510 springs have been identified and discussed in terms of hydrological regions, flow, temperature, sphere of influence, total dissolved solids, $\mathrm{pH}$ and water typing. Examples are provided detailing characteristics of springs associated with faults, karst, salt diapirs, rockfall/alluvial systems and debris avalanche sites. Preliminary findings from a monitoring program of 27 springs are discussed. Future research should focus on identifying additional springs and characterizing associated groundwater dependent ecosystems. Incorporating springs into the provincial groundwater observation well monitoring program could facilitate early warning of drought conditions and other impacts associated with changing climate.
\end{abstract}

\section{RÉSUMÉ}

Les sources de l'île du Cap-Breton ont toujours joué un rôle important dans l'approvisionnement en eau potable, l'amélioration des cours d'eau fréquentés par les salmonidés, la création de coulées de débris recouverts de till et l'exploration de minéraux ou d'hydrocarbures. L'île du Cap Breton procure un aperçu hydrogéologique des racines d'une ancienne chaîne de montagnes, maintenant exhumée, érodée par la glaciation et tectoniquement inactive. Lexhumation et la glaciation survenues il y a environ 140 Ma depuis la période crétacée sont d'une importance particulière pour la formation de sources. Au total, 510 sources ont été identifiées et analysées en ce qui a trait aux régions hydrologiques, aux flux, aux températures, aux sphères d'influence, aux matières dissoutes totales, au $\mathrm{pH}$ et à la typologie de l'eau. Des exemples précisent les caractéristiques de sources associées aux failles, karsts, diapirs de sel, chutes de pierres, systèmes alluviaux et sites d'avalanches de débris. Les premières conclusions d'un programme de surveillance portant sur 27 sources sont en train d'être examinées. La recherche future devrait porter sur l'identification de sources supplémentaires et la caractérisation d'écosystèmes tributaires des eaux souterraines. L'intégration des sources au programme de surveillance des puits d'observation d'eaux souterraines pourrait faciliter la fonction d'alerte précoce lors de conditions de sécheresse et d'autres répercussions associées au changement climatique.

[Traduit par la redaction]

\section{INTRODUCTION}

Over the last two decades recognition of the importance of springs has been growing. The field of ecohydrology (Larsen et al. 2012) has recognized springs as biodiversity hotspots (Sada and Pohlmann 2002; Cantonati et al. 2015), keystone groundwater dependent ecosystems (Springer et al. 2015; Cantonati et al. 2016; Cantonati et al. 2015; Brunke and Gonser 1997), and refugia for rare or unique aquatic and terrestrial life, including ecosystem goods and services species (Stevens et al. 2011; Nichols et al. 2014). Concerns over climate change impacts to spring dependent ecosystems were noted by Klove et al. (2013) and Asjarvi et al. (2015). Springs act as a "canary in the coal mine" for groundwater health (Alley and Alley 2017).

In other aspects trace element geochemistry of spring waters has been used to assess mineral potential (Caron $e t$ al. 2008). Hot springs have been used to aid in understanding 
geothermal systems (Renaut and Jones 2003, Curewitz and Karson 1997). In remote areas springs provide a relatively inexpensive resource to assess regional hydrogeology (Manga 1999). The role of groundwater as an erosive agent through seepage and icings can be important in shaping major landscape features (Nash 1996; Otton and Hilleary 1985; Baker et al. 1990). Springs occurring on continental shelves during Pleistocene low sea level stands are now submerged and recognized as fresh submarine groundwater discharge (SGD) zones, which are important features in managing coastal aquifers and nearshore marine environments (Faure et al. 2002; Fleury et al. 2007; Dimova et al. 2011; Taniguchi et al. 2002; Bakalowicz et al. 2007). Large magnitude terrestrial springs are often regarded as geologic wonders enhancing tourism (Florea and Vacher 2006).

In the early 1900s the documentation and classification of springs began in earnest by the United States Geological Survey (Alfaro and Wallace 1994). A spring inventory system is in use in parts of the United States (Sada and Pohlmann 2002). In Canada Alberta appears to be in the forefront of spring inventory, monitoring and research (Alberta Geological Survey 2017), especially on thermal springs in the southern Cordillera (Grasby and Hutcheon 2001; Grasby and Lepitzki 2002; Borneuf 1983).

Cape Breton Island forms the northeastern part of the Province of Nova Scotia, along the Atlantic seaboard of Canada (Figs. 1a, b). It encompasses an area of approximately $11700 \mathrm{~km}^{2}$, making it the $18^{\text {th }}$ largest island in Canada and $77^{\text {th }}$ largest in the world. It is surrounded by the Atlantic Ocean on the east and the Gulf of St. Lawrence to the north and west. It is separated from mainland Nova Scotia by the Strait of Canso.

The authors' experience indicate that Cape Breton Island springs have played a role in: (1) developing potable groundwater supplies for communities and individuals, (2) supplying bottled water operations, and (3) enhancing important salmonid streams. European medicinal beliefs were associated with springs at Glengarry, Bras d'Or, Cheticamp, Grande Anse, and L'Ardoise (Cross and Goyette 2000). The oil fields of Cape Breton Island in the Lake Ainslie area were first noted as hydrocarbons in springs (McMahon et al. 1986). The importance of springs in creating thin-skinned debris flows, with impact on transportation corridors and riverine systems in Cape Breton Island, were identified by Grant (1994), Wahl et al. (2007) and Finck (1993).

There has been no detailed, government assessment of springs in the province. Preliminary screening was undertaken privately by Cross and Goyette (2000); who identified 51 springs in Cape Breton Island. In Nova Scotia regional water resource evaluations have not focused on springs. It is therefore expected that this research will fill an important gap in understanding the island's fresh water resources.

This paper represents the sixth in a series focusing on what is presently understood about CBI's fresh water resources, to aid in their effective utilization and management. Previous papers in the series discuss: hydrological settings (Baechler and Baechler 2009), karst (Baechler and Boehner 2014), the impact of a changing climate (Baechler 2014), fault aquifers (Baechler 2015), and buried bedrock valley aquifers (Baechler 2017).

Springs are defined for this paper as ecosystems in which groundwater reaches the Earth's surface, either at or near the land-atmosphere interface, or land-water interface (Springer and Stevens 2009).

A brief discussion of paleohydrology is followed by a description of the hydrological setting of the Island. A discussion of the spatial distribution of springs, as well as their physical and chemical characteristics, is provided, along with a more detailed discussion of five different spheres of influence (SOI). The final section documents the development and preliminary results of a spring monitoring program.

\section{PALEOHYDROLOGY}

Cape Breton Island's circa $1 \mathrm{Ga}$ geological history created a complex, lithological and structural terrain through plate collision, mountain building, regional scale faulting, sedimentary basin formation, karstification, opening of the Atlantic Ocean, prolonged exhumation, glaciation, and variable sea level; now molded by a maritime climate, surrounded by the sea. Exhumation and glaciation over approximately $140 \mathrm{Ma}$ since the Cretaceous are of particular relevance to the formation of springs.

The crystalline basement rocks of the island were created through six orogenic cycles, spanning approximately 1200 to $65 \mathrm{Ma}$ (e.g., van Staal and Barr 2012). These events raised the Appalachian mountain belt along the eastern margin of the North American continent, in which CBI is positioned. Erosion of the mountain complex resulted in formation of the Maritimes Sedimentary Basin which overlies the crystalline basement.

Mesozoic erosion created a broad, lowland peneplain of the Appalachian mountain chain (Pascucci et al. 2000). During the Tertiary (65 to $3 \mathrm{Ma}$ ) the Mesozoic peneplain was uplifted and tilted to the east (Nova Scotia Museum 1997). During the subsequent erosional cycle, resistant crystalline basement rocks became more prominent in the landscape, as the surrounding softer sedimentary rocks created the lowlands. Grant (1994) noted that this exhumation provided the island's landscape with two dominant planation surfaces (Fig. 1c). The Tertiary peneplain slopes southeast and maintains its identity as a geomorphic feature across the entire island from the western Cape Breton Highlands at an elevation of over $500 \mathrm{~m}$, to the eastern coast at $30 \mathrm{~m}$. It allowed for karstification, deep weathering and incision by a remarkable dendritic system of gorges and canyons, assumed to predate the last glaciation. A Pliocene peneplain comprises a network of interconnected lowlands ranging from 10 to 200 m elevation, developed mainly on Carboniferous sedimentary rock.

The landscape of the island had therefore largely assumed its present form by pre-Quaternary time. This created strong 

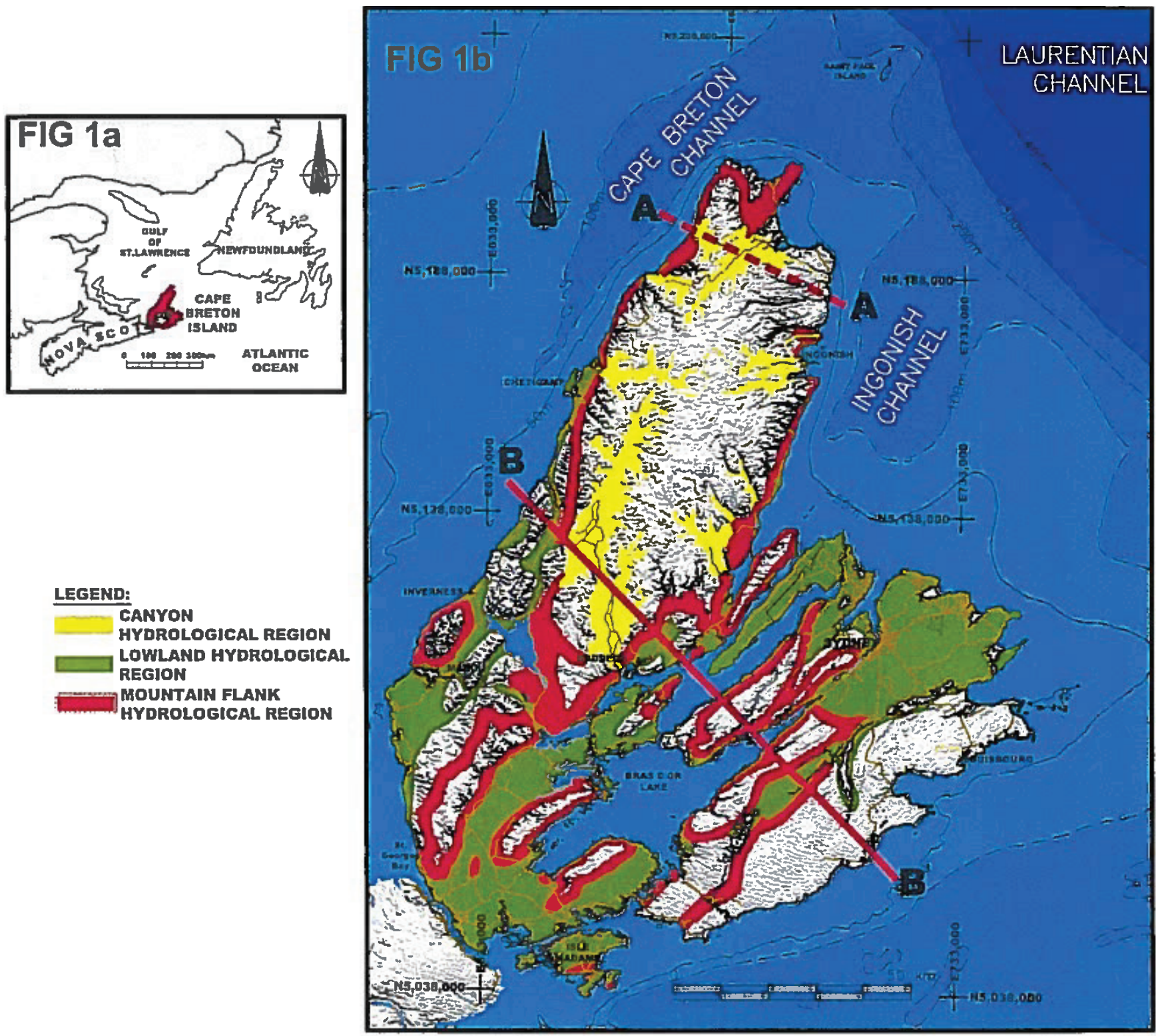

FIG 1C - TOPOGRAPHIC CROSS SECTIONS LOOKING NORTH

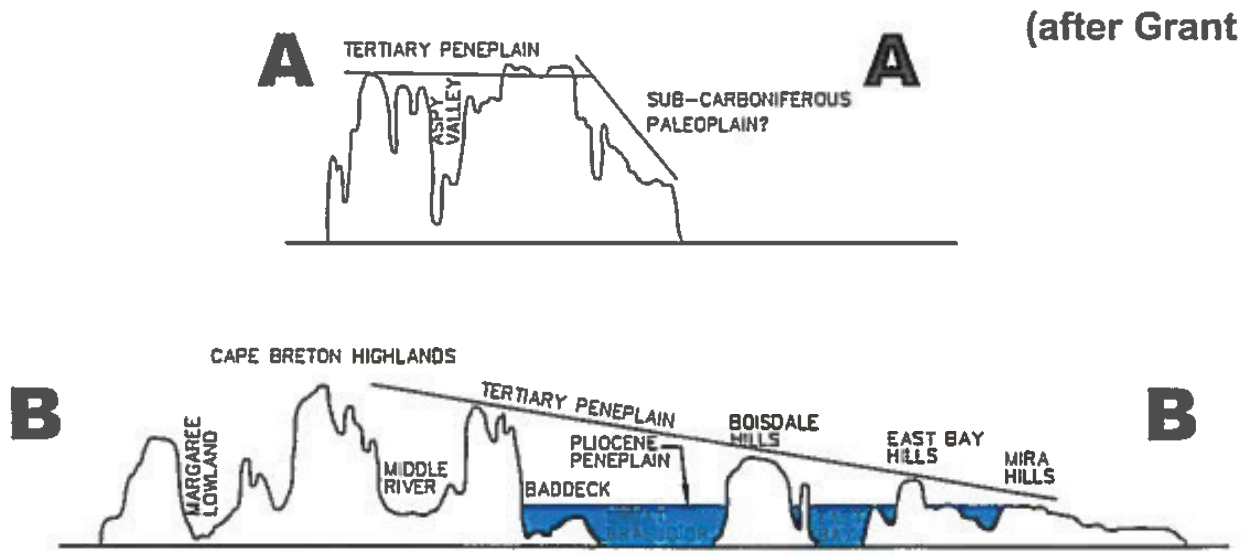

(after Grant 1994)

Figure 1. Regional location map (Fig. 1a), delineating Lowland, Mountain Flank and Canyon Hydrological regions (Fig. 1b) and topographic profiles for ancient peneplains (Fig. 1c). 
landscape contrasts which influenced the course of Quaternary glaciation (Nova Scotia Museum 1997). Glaciation modified the landscape, with scouring and deposition of a wide range of glacial debris from low permeable glacial tills and lacustrine deposits to permeable glacial fluvial outwash sands/gravels, alluvial fans, and talus cones, coupled with karst development. The last remnants of Wisconsinan ice disappeared from the Island circa $10 \mathrm{ka}$, leaving sea level approximately $50 \mathrm{~m}$ lower than present day. It is this final landscape which now drives the present-day groundwater flow systems and spring development.

In summary CBI provides ample opportunity for the formation of springs, due to a coupling of an exhumed Mesozoic paleosurface and Quaternary glaciation.

\section{PRESENT DAY HYDROLOGICAL SETTING}

The Island has a temperate, humid, continental climate, with a 30-year climatic normal (1981-2010) annual precipitation of $1517 \mathrm{~mm}$ and mean annual air temperature of $5.9^{\circ} \mathrm{C}$. These conditions provide for an estimated annual water surplus and deficit using the Thornthwaite method (Thornthwaite 1948) of 987 and $21 \mathrm{~mm}$, respectively. Based upon a moving decadal means analysis (Baechler 2014) the Island's climate is changing with a decline in total annual precipitation of approximately $300 \mathrm{~mm}$, and a rise in mean annual air temperature of $0.8^{\circ} \mathrm{C}$ since the early $1980 \mathrm{~s}$.

Sharpe et al. (2014) positioned CBI regionally in both the Appalachian and Maritimes Basin hydrogeological regions. Baechler and Baechler (2009) locally mapped six hydrological regions over the island (now expanded to nine) by defining areas with characteristic types, numbers and orientations of hydrostratigraphic units (HUs), climate, topographic relief, and forest cover. While the delineation of hydrological regions (Fig $1 \mathrm{~b}$ ) is more applicable, the provincial ecological land classification system (Neily et al. 2017), as noted in Fig. 2, is more commonly in use. The Lowland, Mountain Flank and Canyon Hydrological regions are particularly relevant to the discussion of springs. The Lowland Region coincides with the Carboniferous Lowland of the Ecological Land Classification. The Mountain Flank and Canyon hydrological regions have no similar unique, ecological counterpart, but instead include portions of the Highlands, Avalon Uplands and Carboniferous Lowlands.

The Mountain Flank Hydrological Region encompasses approximately $13 \%$ of the Island. It incorporates the steep transition slopes of up to $400 \mathrm{~m}$ in relief with slopes of 20 to $>75 \%$, between Lowland and Highland regions. It exhibits the most complicated hydrological settings including hydraulically active, strike-slip, dip slip, thrust and normal faults. It is bedrock controlled, with minimal cover of glacial materials. Localized overburden is composed of thick colluvium, in the form of talus rock slopes, alluvial fans and kame terraces.

The Canyon Hydrological Region, encompassing 8\% of the Island, is incised into the crystalline rocks comprising the highland Tertiary peneplain, along large-scale fault systems in various stages of exhumation and hydrogeological development (Baechler 2015). Coarse unconsolidated sediments underlie the valley floors, associated with glacialfluvial, colluvium, and alluvial fan deposits.

The Lowland Hydrological Region on Cape Breton Island covers approximately $24 \%$ of the Island and is developed over the Pliocene peneplain. The region is underlain by a variety of clastic sedimentary bedrock, coal cyclothem sequences and evaporites. Karst is present in various stages of hydrogeological development (Baechler and Boehner 2014). The relief is generally bedrock controlled with a thin veneer of glacial till, resulting in a smooth, undulating terrain with low relief knolls and valleys. A number of broad lowland valleys are underlain by glacial-fluvial deposits in floodplains and buried bedrock valley aquifers (Baechler 2017), which can be underlain by evaporites and argillaceous clastics of the Windsor Group, or arenaceous clastics of the Cumberland or Horton groups.

\section{CAPE BRETON ISLAND SPRINGS}

The springs identified in this paper encompass natural sites, as well as those where natural flow has been exposed by man-made activities (e.g. overflowing wells, mine pools, road cuts, and quarry exposures). The focus of this paper is on those springs noticed during dry weather events, not those only active during storm runoff. Most springs have only been visited once and therefore represent varying seasonal and weather conditions, making statistics more subjective. Twenty-seven springs of varying types were selected for long term monitoring to improve the understanding of the impact of weather and climate change.

Sada and Pohlmann (2002) noted that a spring inventory includes four levels: (1) data mining to review existing information, (2) reconnaissance field surveys, (3) detailed field surveys, and (4) development of a digital database. This paper focuses on the physical and chemical aspects of items 1,2 , and 4 .

The authors have been collecting spring data during self funded research over CBI for $15^{+}$years. The spatial distribution of the data set is not random, as spring identification has usually been through field work conducted for other purposes. The dataset supporting this paper provided information for 510 sites on CBI (Fig. 2), including 42 identified by Cross and Goyette (2000). A total of 27 are used for potable water supplies. It also includes 68 debris avalanches sites, 32 of which were previously identified by Finck (1993) and Wahl et al. (2007). The remaining 36 sites were identified by reviewing air photos for evidence of debris avalanche sites.

Data collection parameters included coordinates of spring discharge sites using a hand-held GPS, site photographs and measurement of flow, specific conductance and temperature. At select sites samples were collected for chemical analysis and/or data loggers were deployed. Debris avalanche sites were not field inspected due to 


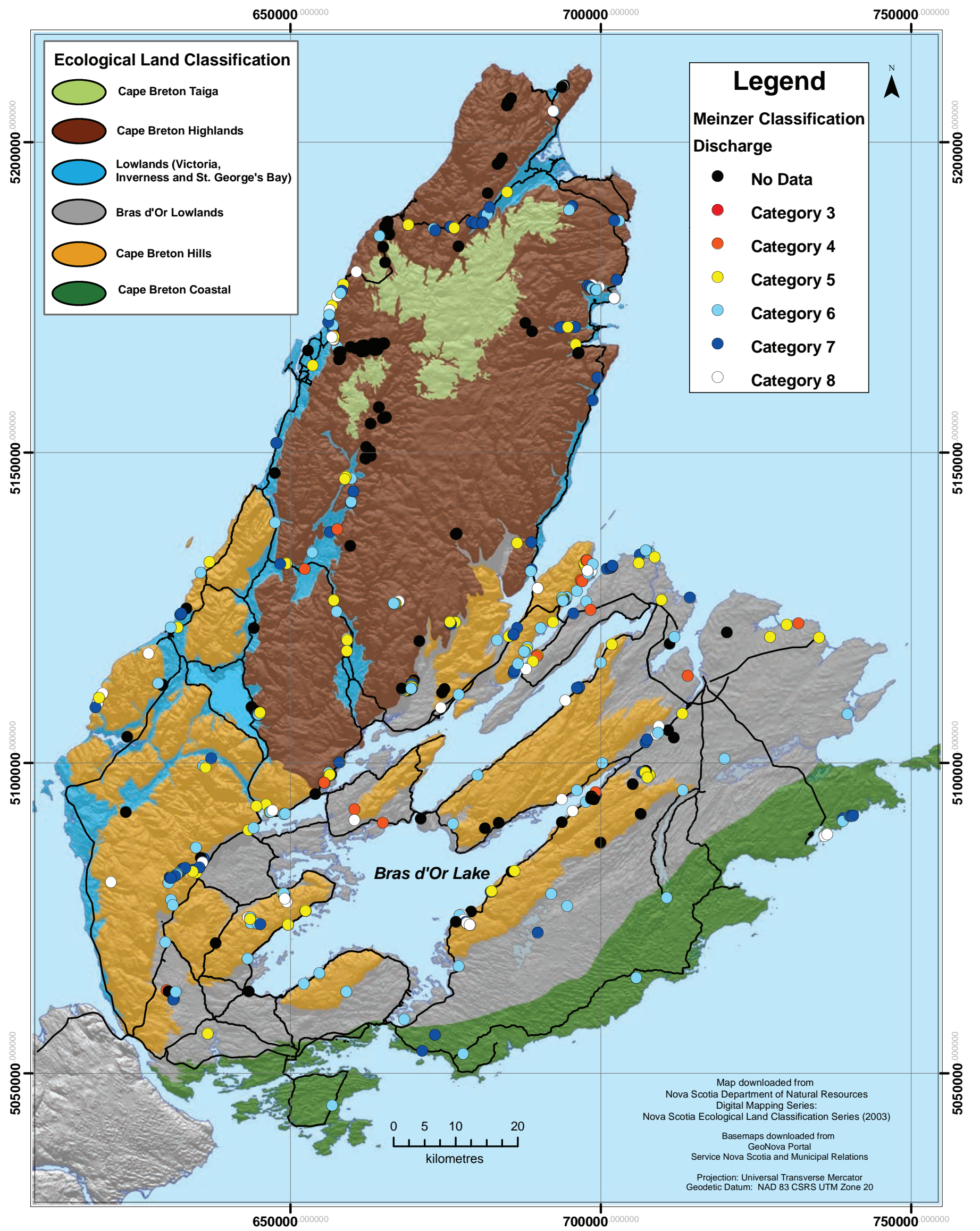

Figure 2. Location of 510 springs, colour coded with Meinzer discharge classification system, within Ecological Land classes. 
remoteness. The groundwater dependent ecosystems (GDE) aspects of springs have not been addressed. All data have been entered into a Geographic Information System (GIS) digital database, which includes up to 37 separate pieces of information for each spring; expanding to a maximum of 89 if a complete chemical analysis was performed. A total of 142 springs (31\%) have at least one chemical analysis. The datasets developed for this paper have been provided to the Nova Scotia Department of Energy and Mines for inclusion within their provincial water resources database.

Springs may be classified on the basis of diverse physical, chemical, biological and socio-cultural indicators; however, no system is perfect (Otton and Hilleary 1985; Cantonati et al. 2016; Springer and Stevens 2009; Alfaro and Wallace 1994). For this paper six indicators have been utilized, including: discharge, temperature, sphere of influence, total dissolved solids, $\mathrm{pH}$ and water type. The relationship between the 510 springs and their hydrological region are summarized in Figure 3.

Although springs were found throughout all hydrological regions, the majority (50\%) were found in the steep slopes of the Mountain Flank Region. The Lowland and Canyon regions exhibited similar percentages comprising a total of $36.1 \%$ of the springs.

\section{Discharge}

The Meinzer (1923) classification system was utilized to describe discharge. The lowest is Category 8 set at less than 0.6 litres per minute (Lpm). This category is used to characterize seepages (Perez 2001).

The range in discharge associated with 384 springs with at least one flow measurement, encompassing a variety of seasons, is summarized in Table 1 and Figure 2. Their relationship to hydrological region is provided in Figure 3 and Table 2, as well as to hydrostratigraphic unit in Figure 4 and Table 3.

No magnitude 1 or 2 springs have been identified to date. The largest magnitude spring was Class 3 , being a combination of flows from four closely spaced springs, with an instantaneous discharge of $7140 \mathrm{Lpm}$ during spring runoff. Twenty-nine Class 4 springs were detected, with flows ranging between 600 to $3030 \mathrm{Lpm}$. The Class 5, 6 and 7 springs accounted for $77.9 \%$ of all reported springs, in roughly equal proportions. Class 8 (or seepages) accounted for $14.4 \%$ of those monitored. The largest magnitude Class 3 spring and $65.5 \%$ of all Class 4 springs occurred within the Mountain Flank Region.

Higher permeability fault zones and karstic limestone are regarded as zones of greater permeability and can result in concentration of high yield springs (Alfaro and Wallace 1994; Buczynski and Rzonca 2011; Sanders et al. 2010). Both hydraulically active faults (Baechler 2015) and karst in limestone, evaporites and marbles (Baechler and Boehner 2014) occur on the Island. In terms of faults, a number of springs have been found associated with strike slip, normal and thrust faults at Kelly's Mountain, Rear Baddeck, Rigwash Valley, and the North Aspy River. The one Class 3 spring was associated with faults in the Structural HU. The Class 4 springs were associated with both the Structural and Karst HUs, with the largest discharge associated with faults at Baddeck and Kelly's Mountain. Karst springs were generally in the lower Class 6 to 7 Meinzer categories. This is expected to be a result of infilling of karst features with glacial debris during the last glaciation.

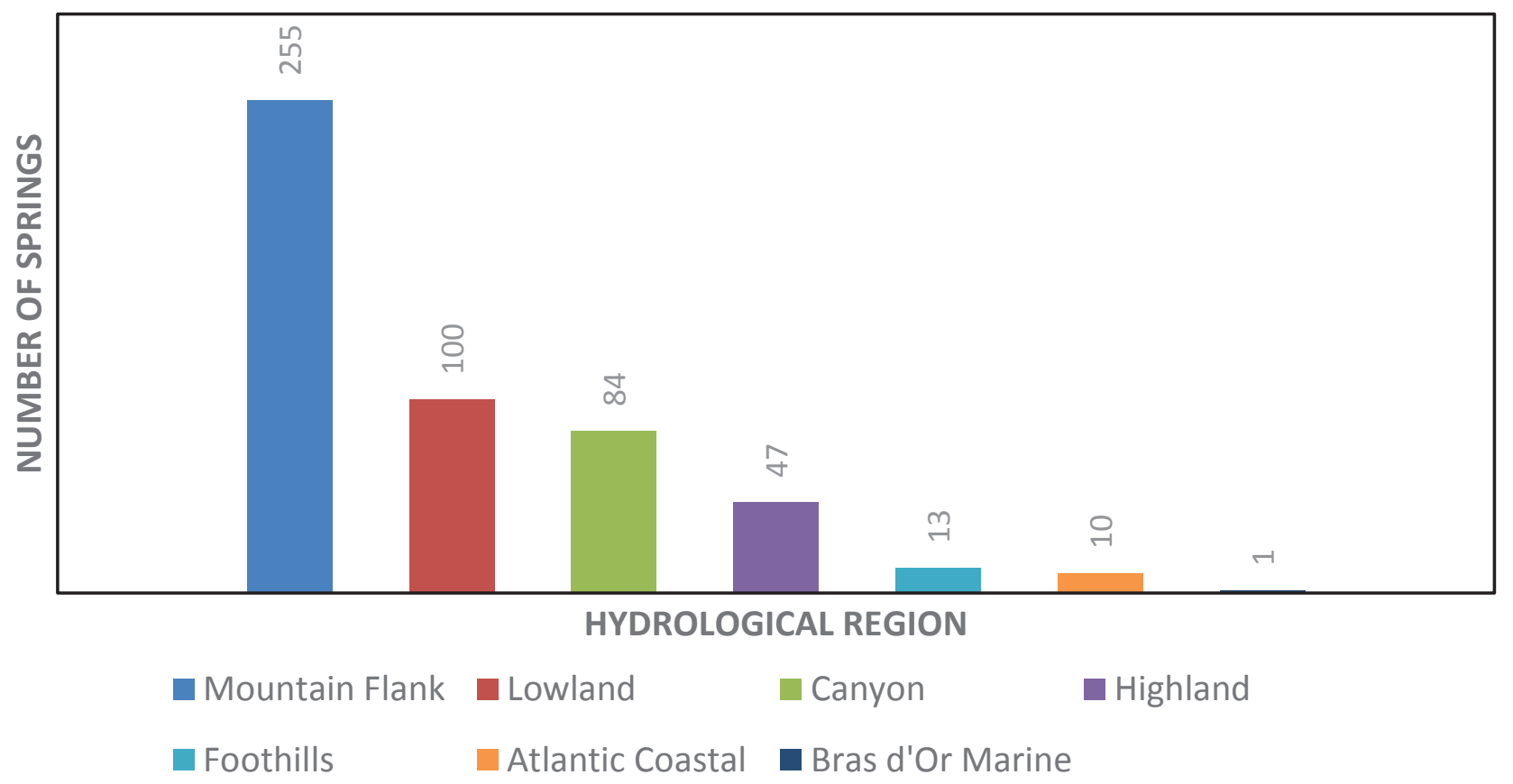

Figure 3. Springs in relation to Hydrological regions. 
Table 1. Range in discharge from 384 springs.

\begin{tabular}{ccc}
\hline $\begin{array}{c}\text { Meinzer } \\
\text { Class }\end{array}$ & $\begin{array}{c}\text { Discharge } \\
(\mathrm{Lpm})\end{array}$ & $\begin{array}{c}\text { Percentage of } \\
\text { Springs }\end{array}$ \\
\hline 1 & $>600000$ & 0 \\
2 & 60000 to 600000 & 0 \\
3 & 6000 to 60000 & 0.3 \\
4 & 600 to 6000 & 7.5 \\
5 & 60 to 600 & 23.7 \\
6 & 6 to 60 & 27.1 \\
7 & 0.6 to 6 & 27.1 \\
8 & $<0.6$ & 14.4 \\
\hline
\end{tabular}

\section{Temperature}

Spring temperatures are described in relation to "hot" or "cold", which at times can be based upon the mean annual air temperature of the region being assessed, which varies with location (Van Everdingen 1972; Otton and Hilleary 1985). Due to lack of consistency in current definitions the terms should always be accompanied by the temperature range and benchmarks used (Pentecost et al. 2003). For the purposes of this analysis, spring water temperature was classified according to Table 4 .

Single temperature measurements were available for 394 springs ( $77 \%$ of the database). The recorded temperatures were mainly in the ambient range. The ambient range of 5 to $10^{\circ} \mathrm{C}$ was based upon consideration of: (1) the $5.9^{\circ} \mathrm{C}$ 1981-2010 normal mean annual air temperature of the Island from Environment Canada's Sydney A station and (2) crustal temperature depths within the active groundwater flow field on the Island, which are predicted to be in the range of 6 to $10^{\circ} \mathrm{C}$ for depths to $150 \mathrm{~m}$ and increasing to 10 to $12^{\circ} \mathrm{C}$ down to $200 \mathrm{~m}$ (Grasby et al. 2009).

The extent of seasonal fluctuations was based upon 19812010 normal monthly mean daily air temperature values ranging from $-5.9^{\circ}$ to $18.0^{\circ} \mathrm{C}$. The temperature of overflows from spring fed pools and small lakes exhibited even higher peaks, with instantaneous seasonal temperatures in the $20^{\circ}$ to $25^{\circ} \mathrm{C}$ range (e.g., Melanie Pond, Dalem Lake and Sugar Camp Lake).

No warm or hot springs have been identified t o $d$ ate. Western Canadian studies have used $10^{\circ} \mathrm{C}$ above mean annual air temperature as defining hot springs (Grasby and Hutcheon 2001; Ferguson and Grasby 2011). Given that the temperatures of shallow springs and spring fed lakes are impacted by seasonal changes in air temperatures, and often exceed $10^{\circ} \mathrm{C}$, the analysis for this paper utilizes body temperature $\left(36.7^{\circ} \mathrm{C}\right)$ as a threshold to define hot springs, irrespective of altitude or pressure, as recommended by Pentecost et al. (2003).

Spring temperatures respond to both solar energy and crustal heat flow. Drury et al. (1987) noted that crustal heat flow varies across the Canadian Appalachians, being lowest in the Carboniferous Magdalen sedimentary basin, which surrounds and underlies the Lowland Hydrological Region of CBI. Up to $10 \mathrm{~km}$ of crust may have been eroded from the basement prior to basin formation, removing much of the radiogenic source of heat. Three geothermal flux measurements from CBI produced low values of 55 to $63 \mathrm{~mW} / \mathrm{m}^{2}$. In addition, crustal backgrounds may be affected by the presence of intrusive magma, volcanism, heat from radioactive elements and heat generated by friction along faults (Alfaro and Wallace 1994); none of which are known to exist on the Island. The distribution of hot springs in other areas can be related to hydraulically active faults (Grasby and Hutcheon 2001) or karstification (Hilberg and Kreuzer 2013) that provide high permeability flow paths for deep circulating, thermal meteoric waters. Although the island has hydraulically active, large fault systems (Baechler 2015) and karst systems (Baechler and Boehner 2014), the absence of thermal springs identified to date may be attributed to low crustal heat flows.

Of note is that geothermal gradients associated with subsea coal mine workings in the Sydney coalfield indicated temperatures of $20^{\circ} \mathrm{C}$ at $600 \mathrm{~m}$ depth (Forgeron personal communication 2018). Overflow mine pool springs in the Sydney area, however, exhibited consistent temperatures in the flooded Gardiner and Franklyn sites in the ambient range (averaging 7.6 and $8.1^{\circ} \mathrm{C}$, respectively).

Table 2. Relationship of spring discharge to hydrological region.

\begin{tabular}{ccccccc}
\hline $\begin{array}{c}\text { Hydrological } \\
\text { Region }\end{array}$ & $\begin{array}{c}\text { Meinzer } \\
\text { Class 8 (\%) }\end{array}$ & $\begin{array}{c}\text { Meinzer } \\
\text { Class 7 (\%) }\end{array}$ & $\begin{array}{c}\text { Meinzer } \\
\text { Class 6 (\%) }\end{array}$ & $\begin{array}{c}\text { Meinzer } \\
\text { Class 5 (\%) }\end{array}$ & $\begin{array}{c}\text { Meinzer } \\
\text { Class 4 (\%) }\end{array}$ & $\begin{array}{c}\text { Meinzer } \\
\text { Class 3 (\%) }\end{array}$ \\
\hline Mountain Flank & 12.9 & 25.8 & 24.4 & 27.2 & 9.1 & 0.5 \\
Canyon & 3.1 & 46.9 & 21.9 & 21.9 & 6.3 & \\
Lowland & 13.8 & 21.8 & 26.4 & 29.9 & 10.8 & 2.7 \\
Highland & 27 & 21.6 & 37.8 & 12.5 & & \\
Foothills & 12.5 & 25 & 50 & 10 & & \\
Atlantic Coastal & 20 & 30 & 40 & & & \\
Bras d'Or Marine & 100 & & & & & \\
\hline
\end{tabular}




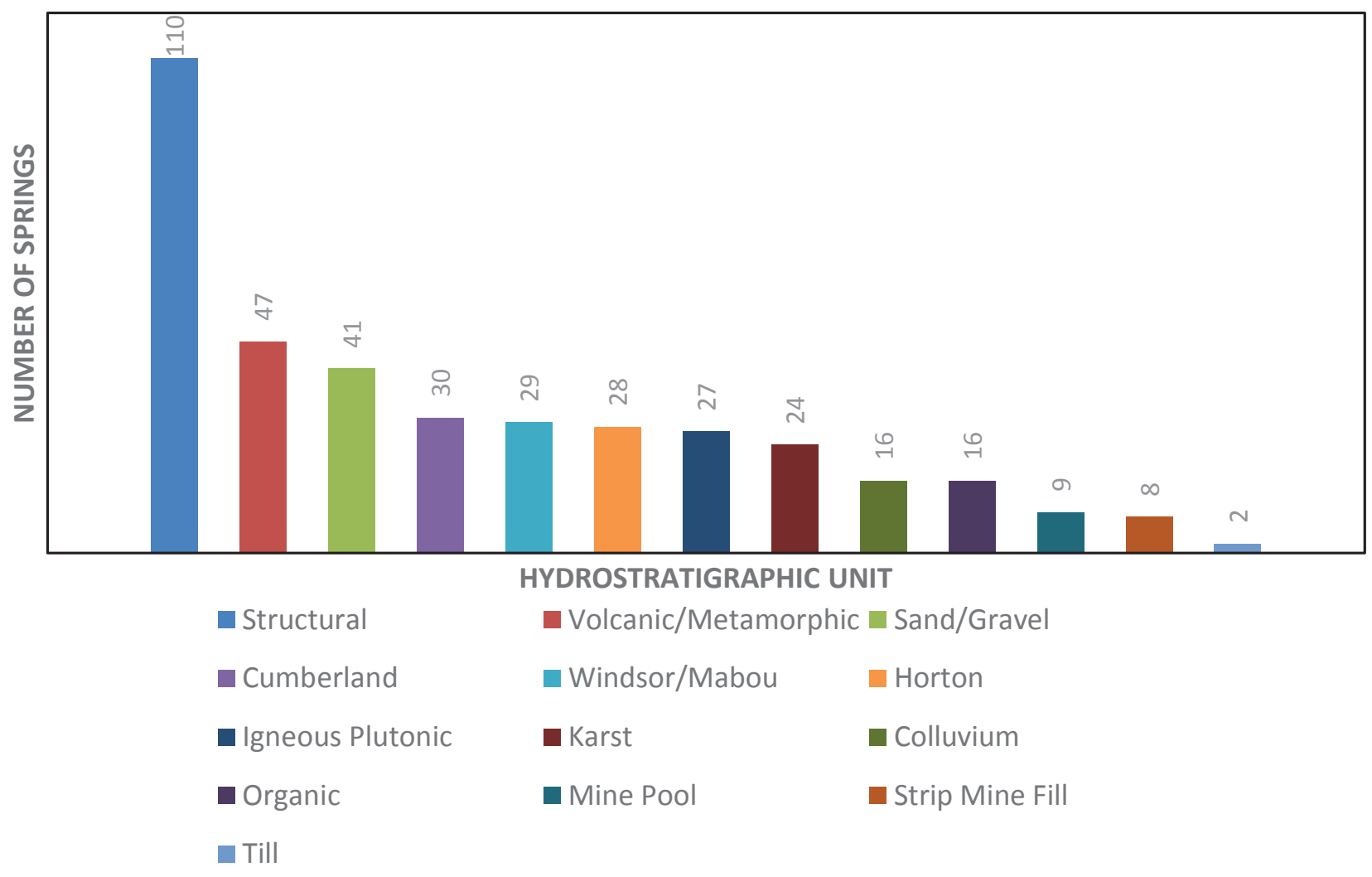

Figure 4. Springs in relation to Hydrostratigraphic unit.

\section{Spheres of influence}

Springer and Stevens (2009) identified 12 spheres of influence (SOI) into which springs are discharged. This list was expanded to 19 SOIs (Table 5) to capture the variability of Cape Breton Island springs. The number of springs within each category is outlined in Figure 5. SOIs were determined from existing bedrock and surficial geological mapping, coupled with visual field inspection. Defining the primary SOI was difficult since in some cases multiple SOIs applied and the underlying geology was unknown.

The largest number of springs is related to faults $(20.6 \%)$.

Table 3. Relationship of spring discharge to hydrostratigraphic unit.

\begin{tabular}{ccccccc}
\hline $\begin{array}{c}\text { Hydrostratigraphic } \\
\text { Unit }\end{array}$ & $\begin{array}{c}\text { Meinzer } \\
\text { Class 8 }\end{array}$ & $\begin{array}{c}\text { Meinzer } \\
\text { Class 7 }\end{array}$ & $\begin{array}{c}\text { Meinzer } \\
\text { Class 6 }\end{array}$ & $\begin{array}{c}\text { Meinzer } \\
\text { Class 5 }\end{array}$ & $\begin{array}{c}\text { Meinzer } \\
\text { Class 4 }\end{array}$ & $\begin{array}{c}\text { Meinzer } \\
\text { Class 3 }\end{array}$ \\
\hline Windsor/Mabou & 3 & 3 & 16 & 2 & 5 & \\
Karst & 4 & 8 & 2 & 5 & 5 & 1 \\
Structural & 2 & 30 & 28 & 35 & 14 & \\
Horton & 3 & 9 & 10 & 6 & & \\
Organic & 3 & 5 & 5 & 3 & & \\
Igneous Plutonic & 7 & 8 & 7 & 3 & & \\
Volcanic/ & 14 & 12 & 14 & 7 & & \\
Metamorphic & 3 & 9 & 8 & 8 & 2 & \\
Cumberland & 3 & 12 & 7 & 9 & & \\
Sand/Gravel & 13 & 5 & 3 & 5 & 1 \\
Colluvium & 2 & 1 & 1 & & & \\
Till & & & 1 & 5 & 5 & \\
Mine Pool & 2 & & 3 & 5 & & \\
Strip Mine fill & & & & 5 & & \\
\hline
\end{tabular}


Table 4. Range in spring temperatures based on one measurement taken at source.

\begin{tabular}{ccc}
\hline Class & $\begin{array}{c}\text { Temperature } \\
\text { Range }\end{array}$ & $\begin{array}{c}\text { Percentage of } \\
\text { Springs }\end{array}$ \\
\hline Ambient & 5 to $10^{\circ} \mathrm{C}$ & $72.60 \%$ \\
Seasonal & 0 to $5^{\circ}$ and 10 to $20^{\circ} \mathrm{C}$ & $27.40 \%$ \\
Warm & 20 to $38^{\circ} \mathrm{C}$ & $0 \%$ \\
Hot/thermal & $>38^{\circ} \mathrm{C}$ & $0 \%$ \\
\hline
\end{tabular}

The next three most common SOIs have similar percentages (13 to 13.5\%), relating to shallow and steep slopes, as well as debris avalanches. Given the difficulty in defining the underlying geology it is possible that some of the Hillslope steep springs may be fault controlled. The relationship between SOI and discharge is presented in Figure 5 and Table 6 . The highest discharges (categories 4 and 3 ) are related to faults and karst, with the next highest discharges associated with the rockfall/alluvial systems. The karst and hillslope
SOIs exhibit a large variability in discharges with Meinzer classes ranging from 8 to 4 .

\section{Chemistry}

Specific conductance (SC) is utilized as the primary chemical indicator for total dissolved solids (TDS). There is a range of conversion factors in the literature (Hem 1985) depending upon the nature of the solutes. Hem (1985) gives a range between 0.55 to $0.75 \mathrm{x}$ SC. The 114 samples from this spring data set with both TDS (ranging from 13 to $73,000 \mathrm{mg} / \mathrm{L}$ ) and SC provided a mean of 0.59 and median of 0.57 . which agrees with that found for other areas of the province (J. Drage and G. Kennedy, personal communication 2018). For the purpose of this paper a 0.6 conversion factor was employed. A total of 411 springs (81\%) have SC available. A total of 151 springs have a chemical analysis, allowing for a more robust assessment of chemistry. A total of $50 \%$ of the SC measurements represent the Mountain Flank region, $31 \%$ the Lowland region; 9\% the Highland region, $6 \%$ the Foothill region and 2\% each of the Canyon and Atlantic

Table 5. Spheres of Influence for Cape Breton Springs.

\begin{tabular}{|c|c|}
\hline Sphere of Influence & Description \\
\hline $\begin{array}{l}\text { Hillslope Steep - } \\
\qquad \text { Fault }\end{array}$ & $\begin{array}{l}\text { emerges from confined or unconfined aquifers on a steep hillslope ( } 20 \text { to } 60 \text { degrees) underlain by a known } \\
\text { major fault zone }\end{array}$ \\
\hline Hillslope Shallow & emerges from confined or unconfined aquifers on shallow slopes ( 5 to 20 degrees) \\
\hline Debris Avalanche & spring discharge creates thin skinned debris flows \\
\hline Hillslope Steep & emerges from confined or unconfined aquifers on a steep hillslope (20 to 60 degrees) \\
\hline Overflow Well & overflowing dug or drilled well \\
\hline $\begin{array}{l}\text { Hanging Garden - } \\
\text { coastal wave cliff }\end{array}$ & springs/seeps discharging out of overburden and bedrock exposures along wave cliffs \\
\hline $\begin{array}{l}\text { Rockfall/Alluvial } \\
\text { Systems }\end{array}$ & flow emerging from the toe of talus and scree slopes, alluvial fans and kame terraces along steep slopes \\
\hline $\begin{array}{l}\text { Hillslope Shallow- } \\
\text { Valley Floor }\end{array}$ & emerges from very low slopes ( $<5$ degrees) over floodplains \\
\hline Rheocrene & springs flowing directly into a defined channel \\
\hline Helocrene & $\begin{array}{l}\text { emerges from low gradient wetlands; often indistinct or multiple sources seeping from shallow unconfined } \\
\text { aquifers }\end{array}$ \\
\hline Karst terrain & underlain by hydraulically active karst terrain \\
\hline Mine Pool & flooded underground mine workings creating a mine pool coming to surface \\
\hline Karst Sinkhole & overflow from a sinkhole \\
\hline $\begin{array}{l}\text { Reclaimed Surface } \\
\text { Mine }\end{array}$ & discharging from spoil materials infilling abandoned reclaimed strip mines and/or flooded quarries \\
\hline $\begin{array}{l}\text { Hanging Garden - } \\
\quad \text { road cut }\end{array}$ & spring/seeps discharging out of overburden and bedrock exposures in road embankments \\
\hline Salt Diapir & flow from centre or edge of salt diapirs exposed at surface \\
\hline Limnocrene & discharge from spring fed lakes resulting from emergence of confined or unconfined aquifers in pool(s) \\
\hline $\begin{array}{l}\text { Hanging Garden - } \\
\quad \text { Quarry }\end{array}$ & discharging from a quarry face \\
\hline Karst Cave & overflow from a karst cave \\
\hline
\end{tabular}




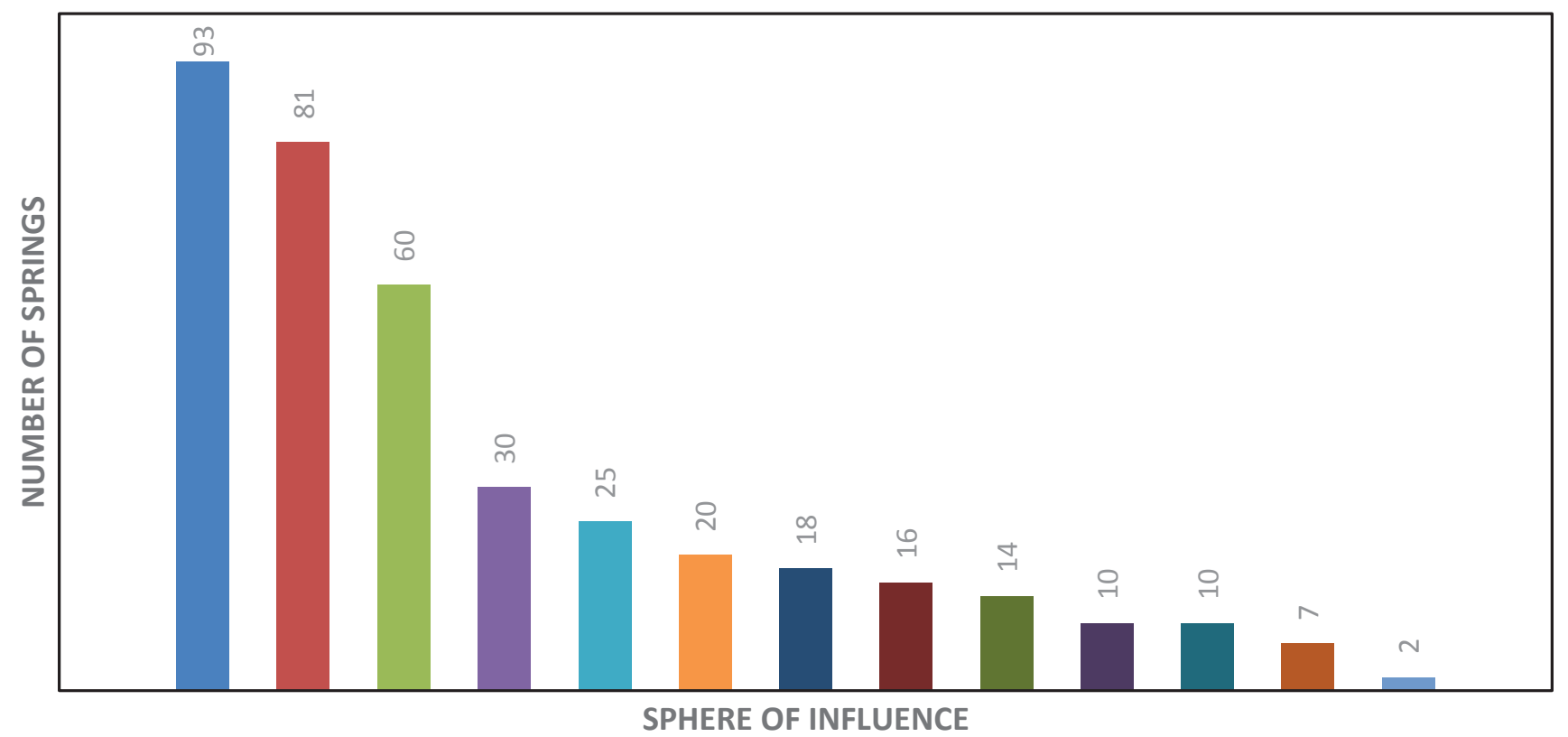

\begin{tabular}{|c|c|c|c|}
\hline - Fault & - Hillslope shallow & Hillslope steep & - Hanging Gardens $\square$ Karst \\
\hline Rockfall/Alluvial & Helocrene & - Rheocrene & Overflow wells \\
\hline Strip Mine & - Salt Diapir & - Limnocrene & \\
\hline
\end{tabular}

Figure 5. Springs in relation to Sphere of Influence.

Coastal regions. The dataset was classified according to TDS, water typing and $\mathrm{pH}$ if data were available.

The TDS categories are refined after Davis and DeWiest (1966), to highlight the ranges observed in Cape Breton Island. Both the spatial distribution (Fig. 6) and concentra- tions (Table 7) of TDS in spring water were highly variable ranging between 38 and 73,000 $\mathrm{mg} / \mathrm{L}$. This variability was especially evident within the Mountain Flank and Lowland regions.

Springs in all regions were predominately hyperfresh to

Table 6. Relationship of Spheres of Influence to number of springs in each discharge category.

\begin{tabular}{|c|c|c|c|c|c|c|}
\hline $\begin{array}{l}\text { Sphere of } \\
\text { Influence }\end{array}$ & $\begin{array}{c}\text { Meinzer } \\
\text { Class } 8\end{array}$ & $\begin{array}{c}\text { Meinzer } \\
\text { Class } 7\end{array}$ & $\begin{array}{c}\text { Meinzer } \\
\text { Class } 6\end{array}$ & $\begin{array}{c}\text { Meinzer } \\
\text { Class } 5\end{array}$ & $\begin{array}{c}\text { Meinzer } \\
\text { Class } 4\end{array}$ & $\begin{array}{c}\text { Meinzer } \\
\text { Class } 3\end{array}$ \\
\hline Karst & 4 & 6 & 2 & 4 & 9 & \\
\hline Hillslope steep & 10 & 15 & 23 & 10 & 2 & \\
\hline Hillslope steep fault & 2 & 29 & 23 & 27 & 11 & 1 \\
\hline Hillslope shallow & 17 & 21 & 24 & 18 & 1 & \\
\hline Helocrene & 3 & 6 & 6 & 3 & & \\
\hline limnocrene & 1 & & & & 1 & \\
\hline Rheocrene & 3 & 4 & 5 & 4 & & \\
\hline Mine Pool & 1 & & 1 & 7 & 1 & \\
\hline Hanging Gardens & 7 & 15 & 5 & 3 & & \\
\hline Overflow wells & 1 & 2 & 6 & 5 & & \\
\hline Rockfall/Alluvial & 2 & 4 & 4 & 6 & 4 & \\
\hline Reclaimed surface mine & & & 4 & 5 & 1 & \\
\hline Salt Diapir & 3 & 2 & & 2 & & \\
\hline
\end{tabular}

Note: Karst includes karst sinkhole, cave, and terrain; Hillslope Shallow includes those on valley floors; Hanging Gardens includes wave cliff, road cuts, and quarries. 


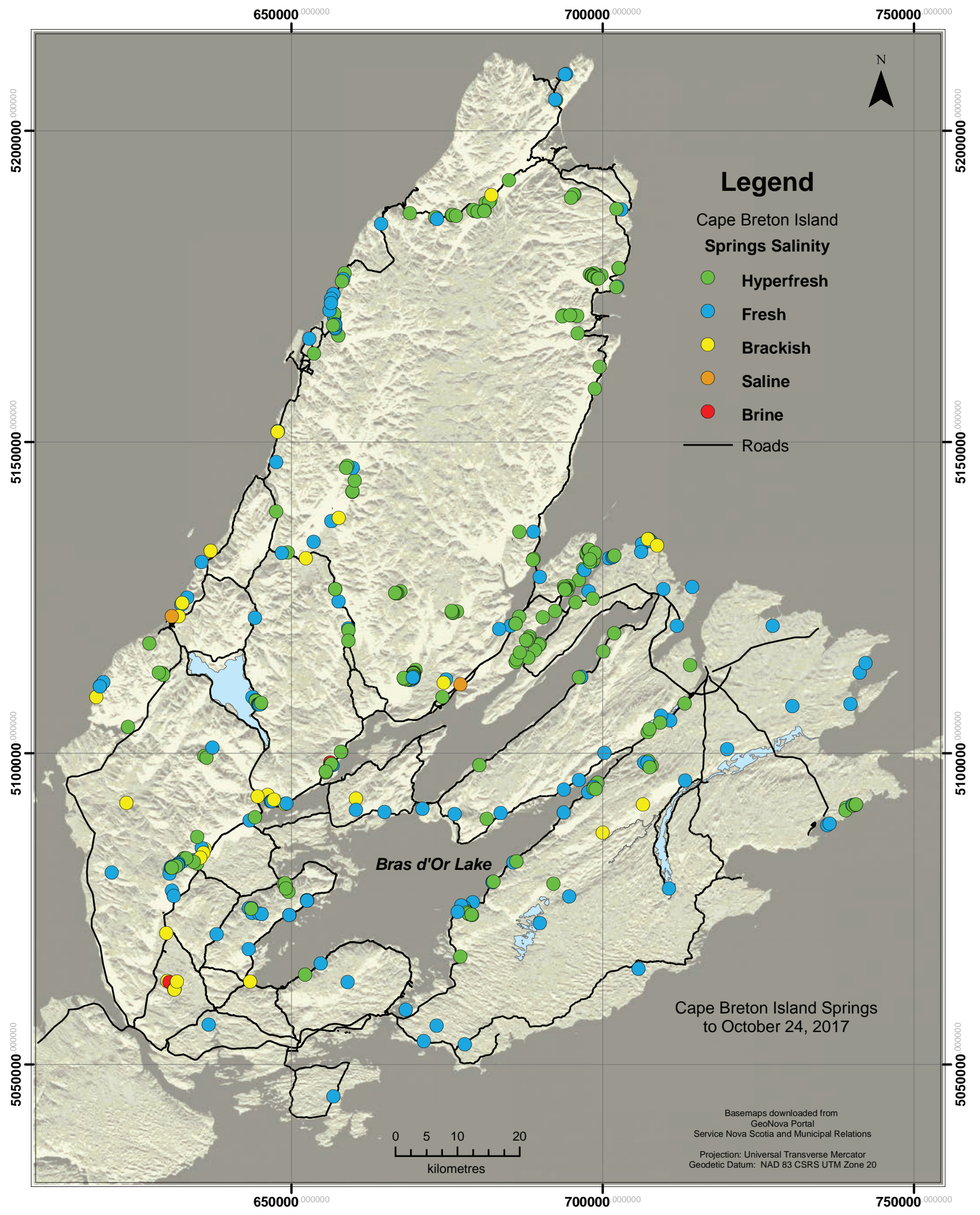

Figure 6. Location of springs with colour coded salinity values. 
Table 7. Relationship of total dissolved solids to hydrological region.

\begin{tabular}{|c|c|c|c|c|c|c|c|}
\hline $\begin{array}{l}\text { Hydrological } \\
\text { Region } \\
\text { Range }(\mathrm{mg} / \mathrm{L})\end{array}$ & Hyperfresh & $\begin{array}{l}\text { Fresh } \\
101-1000\end{array}$ & $\begin{array}{l}\text { Slightly } \\
\text { saline }\end{array}$ & $\begin{array}{l}\text { Moderately } \\
\text { saline }\end{array}$ & Very saline & Brine & $\begin{array}{c}\text { Number Springs } \\
\text { per region }\end{array}$ \\
\hline & & & & & & & \\
\hline Mountain Flank & 129 & 87 & 7 & 3 & & 2 & 228 \\
\hline Lowland & 32 & 42 & 11 & 4 & 1 & 1 & 91 \\
\hline Highlands & 24 & 14 & & & & & 38 \\
\hline Canyon & 24 & 6 & 2 & & & & 32 \\
\hline Foothills & 2 & 7 & 1 & 1 & & 1 & 12 \\
\hline Atlantic Coastal & 5 & 5 & & & & & 10 \\
\hline $\begin{array}{c}\text { Number of springs } \\
\text { per category }\end{array}$ & 216 & 161 & 21 & 8 & 1 & 4 & 411 \\
\hline
\end{tabular}

fresh. The Lowland region exhibited the most springs with TDS elevated above fresh, followed by the Mountain Flank region. Springs in all SOIs were predominately hyperfresh and fresh (Table 8). Brines were found at two sites associated with a fault and within a gypsum quarry. The dominance of hyperfresh and fresh categories within the fault zones is expected to be a function of upgradient granitoid and metamorphic rock types.

A total of five core chemical types of spring water are found within the full chemistry dataset $(\mathrm{n}=150)$ (Table 9). The most common water type was calcium-bicarbonate, with calcium-sulfate and sodium-chloride the next most common. The Lowland and Mountain Flank regions exhibit the most diversity of water types, including the largest variety of mixed types.

The $\mathrm{pH}$ of spring waters (Table 10) in all but the Atlantic Coastal hydrological region was primarily neutral to moderately basic. The exceptions varied from alkaline $\mathrm{pH}$ with limestones, to acidic $\mathrm{pH}$ associated with coal mine pools and strip mines in the Lowland region. In the Atlantic Coastal region, the abundance of wetlands and scarcity of springs is expected to account for the lower $\mathrm{pH}$ range. The Lowland region is also associated with a lower $\mathrm{pH}$ range, due in part to mine pools and the influence of coal seams.

Precipitates and mineral deposits associated with springs have typically been noted with hot springs (Renaut and Jones 2003) and limestone-precipitating springs (Cantonati et al. 2016). No such deposits have been discovered on the Island to date. However, iron precipitates, floc and algae have been noted associated with acid drainage, mine pools and reclaimed strip mine drainage, as well as localized wetlands.

\section{SELECT SPHERES OF INFLUENCE}

The following section provides a more detailed description of five SOIs.

Table 8. Relationship of specific conductance to sphere of influence.

\begin{tabular}{ccccccc}
\hline $\begin{array}{c}\text { Sphere of } \\
\text { Influence }\end{array}$ & $\begin{array}{c}\text { Hyper- } \\
\text { fresh }\end{array}$ & Fresh & $\begin{array}{c}\text { Slightly } \\
\text { saline }\end{array}$ & $\begin{array}{c}\text { Moderately } \\
\text { saline }\end{array}$ & $\begin{array}{c}\text { Very } \\
\text { saline }\end{array}$ & Brine \\
\hline Karst & 12 & 7 & 6 & 2 & & \\
Hillslope Steep & 47 & 15 & & & 1 & \\
Hillslope steep-fault & 59 & 37 & 1 & & & \\
Hillslope shallow & 48 & 33 & 2 & 1 & \\
Helocrene & 14 & 3 & & 1 & \\
Limnocrene & 1 & 2 & & & \\
Rheocrene & 7 & 8 & & 2 & \\
Mine Pool & 1 & 7 & 1 & & \\
Hanging Gardens & 11 & 11 & 2 & & \\
Overflow Wells & 4 & 21 & 5 & 1 & & \\
Rockfall/Alluvial & 12 & 8 & & & \\
Reclaimed surface mine & & 6 & 3 & 1 & \\
Salt Diapir & & 3 & 2 & & \\
\hline
\end{tabular}


Table 9. Relationship of water type to hydrologic region.

\begin{tabular}{ccccccc}
\hline Water Type & $\mathrm{Ca}_{-} \mathrm{HCO}_{3}$ & $\mathrm{Ca}_{-} \mathrm{SO}_{4}$ & $\mathrm{Na}-\mathrm{Cl}$ & $\mathrm{Na}-\mathrm{HCO}_{3}$ & $\mathrm{Na}-\mathrm{SO}_{4}$ & Mixed \\
\hline Highlands & 6 & & 5 & & & 2 \\
Canyon & 1 & & 1 & & & 1 \\
Mountain Flank & 30 & 9 & 18 & & 1 & 18 \\
Foothills & 2 & & 4 & 1 & & 2 \\
Lowland & 12 & 12 & 9 & & 1 & 12 \\
Atlantic Coastal & 1 & & 1 & 1 & & \\
\hline
\end{tabular}

\section{Hillslope Steep Fault SOI}

Deep crustal faults on the Island were created during the formation of the Appalachian mountain belt and later Mesozoic rifting. Cenozoic exhumation brought these features near to the surface and into the active groundwater flow field as a hydraulically active Structural HU (Baechler 2015). Since these features are usually found underlying the steep transition slopes (Fig. 7) between the lowland and highland peneplains, the topographic relief also supports spring formation.

This SOI encompasses most of the high discharge springs. A total of 105 springs (20.6\% of total) were classified under this SOI. Five sites encompassed closely spaced springs; termed spring fields (Fig 7). The largest spring field was located at Rear Baddeck, with 45 springs spread over $2.5 \mathrm{~km}$ of strike length. The remaining four sites included Kelly's Mountain with 6 springs along $0.9 \mathrm{~km}$, Bucklaw with 20 springs along $13 \mathrm{~km}$, Melford with 11 springs over $2.5 \mathrm{~km}$ and East Lake Ainslie with 7 springs along $0.6 \mathrm{~km}$. While the Rigwash valley exhibits numerous springs, which are potentially fault controlled, the springs tend to discharge from overlying rockfall/alluvial systems at surface and are discussed within that SOI.

Instantaneous discharges within faults were quite variable ranging from Meinzer Category 3 to 8 . Faults included the most Category 4 springs (12) of the SOIs, with discharge ranging between 610 and $2250 \mathrm{Lpm}$. Discharge from the one
Category 3 spring, which was an accumulation of flow from four closely spaced springs, was measured at $7140 \mathrm{Lpm}$. Discharge at five monitored springs with sufficient data (Table 11) showed variable flow ( $>100 \%)$, while one spring showed sub variable flow (64\%) and one showed constant flow (12\%).

Single temperature measurements showed mainly ambient conditions, with ten springs exhibiting seasonal temperature fluctuations and 12 with no data. One site (\#307) had a temperature data logger recording between April 2016 and September 2017. The data indicated ambient conditions with temperatures ranging between $6.5^{\circ}$ and $7.4^{\circ} \mathrm{C}$. Although it is likely that the faults could allow deeper, warmer waters to the surface, no thermal springs have been detected to date.

Given the wide range in hydrologic settings there is a notable variability in instantaneous SC values, indicating 57\% hyperfresh, $34 \%$ fresh, $7 \%$ unknown and $2 \%$ other. The latter includes one slightly saline spring $(2467 \mathrm{uS} / \mathrm{cm})$ and one hypersaline spring $(104,400 \mathrm{uS} / \mathrm{cm})$.

Thirty springs had at least one water chemical analysis. Nineteen of these springs were hyperfresh, exhibiting a wide range of mixed water types and two core water types: calciumbicarbonate $(\mathrm{n}=8)$ and sodium-chloride $(\mathrm{n}=3)$. Ten of the springs exhibited fresh water, either calcium-bicarbonate or sodium-chloride type, and three were a mixed water type. The $\mathrm{pH}$ values were all neutral to moderately basic, which appears anomalous given the low TDS. The hypersaline

Table 10. Relationship of $\mathrm{pH}$ to hydrological region.

\begin{tabular}{|c|c|c|c|c|c|c|c|c|}
\hline $\begin{array}{l}\text { Hydrological } \\
\text { Setting } \\
\text { Range (units) }\end{array}$ & $\begin{array}{l}\text { Acid } \\
<3.0\end{array}$ & $\begin{array}{l}\text { Strong } \\
\text { Acid } \\
3.1-5.0\end{array}$ & $\begin{array}{c}\text { Moderately } \\
\text { Acid } \\
5.1-6.4\end{array}$ & $\begin{array}{l}\text { Neutral } \\
6.5-7.5\end{array}$ & $\begin{array}{c}\text { Moderately } \\
\text { Basic } \\
7.6-8.5\end{array}$ & $\begin{array}{l}\text { Strong } \\
\text { Basic } \\
8.6-11.0\end{array}$ & $\begin{array}{c}\text { Alkaline } \\
>11.0\end{array}$ & Total \\
\hline Highlands & & 1 & 2 & 5 & 5 & & & 13 \\
\hline Canyon & & & & 2 & 1 & & & 3 \\
\hline Mountain Flank & & & 3 & 28 & 44 & & & 75 \\
\hline Foothills & & 1 & & 5 & 2 & 1 & & 9 \\
\hline Lowland & 1 & 4 & 10 & 19 & 14 & & & 48 \\
\hline Atlantic Coastal & & 1 & 1 & 1 & & & & 3 \\
\hline Total & 1 & 7 & 16 & 60 & 66 & 1 & & 151 \\
\hline
\end{tabular}




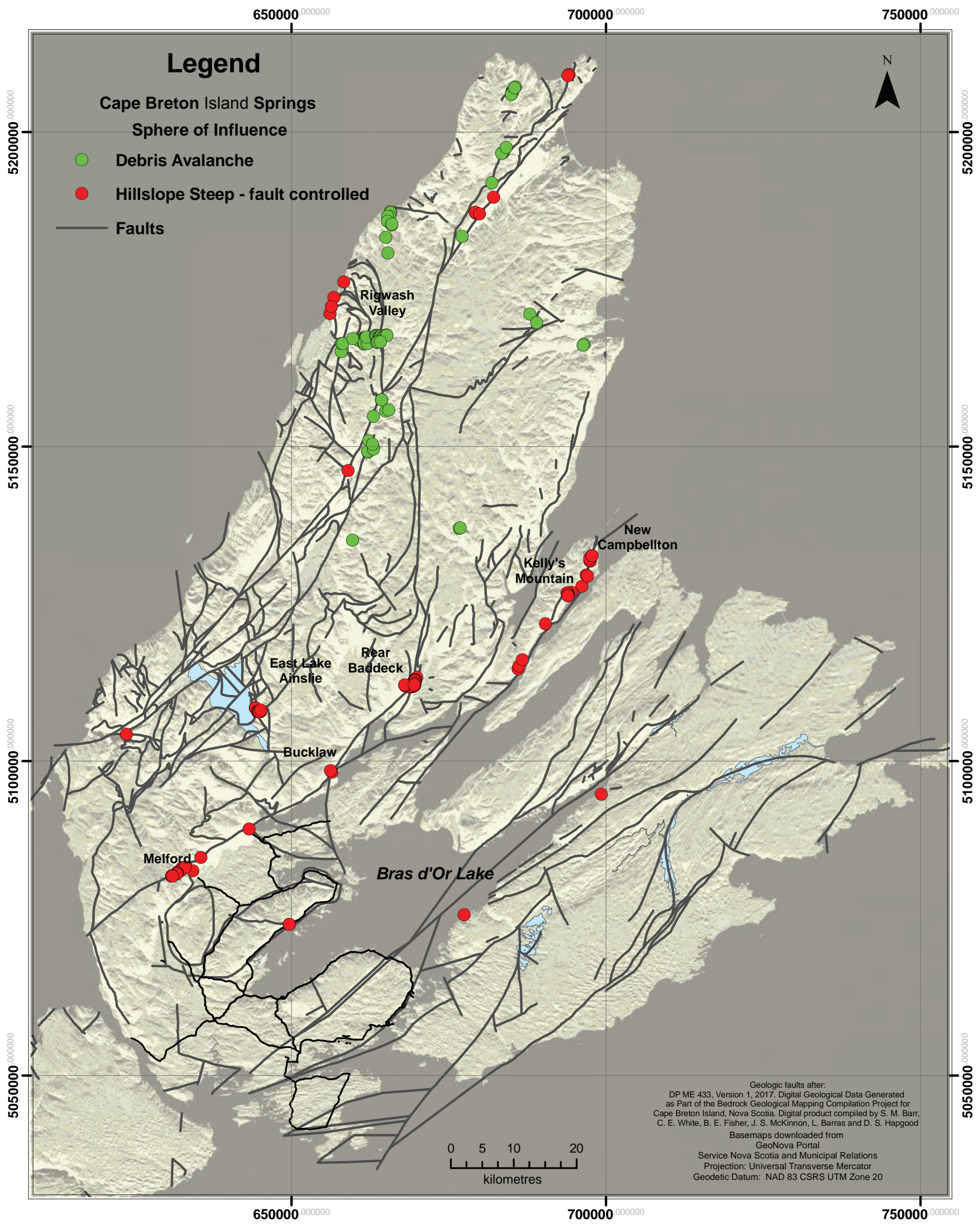

Figure 7. Location of springs related to Fault and Debris Avalanche SOI. 
Table 11. Discharge variability related to Fault springs.

\begin{tabular}{cccccc}
\hline Location(Spring \#) & $\begin{array}{c}\text { No. of } \\
\text { samples }\end{array}$ & Monitoring Period & $\begin{array}{c}\text { Maximum Flow } \\
\text { (Lpm) }\end{array}$ & $\begin{array}{c}\text { Minimum Flow } \\
\text { (Lpm) }\end{array}$ & $\begin{array}{c}\text { Variability } \\
\text { Index (\%) }\end{array}$ \\
\hline Rear Baddeck (\#224) & 6 & May 2015 to May 2017 & 6370 & 375 & 174 \\
Rear Baddeck (\#55) & 9 & June 2014 to May 2017 & 390 & 85 & 131 \\
Rear Baddeck (\#358) & 8 & Dec. 2014 to May 2017 & 34 & 30 & 12 \\
Rear Baddeck (\#307) & 4 & April 2106 to May 2017 & 860 & 460 & 64 \\
Kelly's Mtn (\#76) & 13 & Sept 1987 to May 2017 & 1025 & 150 & 267 \\
\hline
\end{tabular}

NOTE: Variability Index (Meinzer 1923) calculated as: (100) (maximum flow - minimum flow / average flow of all measurements). Variability Index categories are defined as: constant spring not more than $25 \%$; sub variable spring more than $25 \%$ but not more than $100 \%$; variable spring more than $100 \%$.

spring was a dominant sodium-chloride type with a neutral $\mathrm{pH}$ (7.3). None of these springs exhibited any precipitates at their outfalls.

\section{Karst SOI}

Approximately 23\% of Cape Breton Island consists of a wide variety of bedrock (metacarbonates, carbonates and evaporites), which has the potential for karst development. Lowland karst units are generally characterized by broadscale, till-covered, thick evaporite sequences. Found within this zone are solution trenches near basin boundaries, salt diapirs and extensive foundering zones due to salt dissolution, which led to the development of karst breccias to depths exceeding $300 \mathrm{~m}$ (Baechler and Boehner 2014).

A total of 28 springs (5.5\% of all springs) were identified within three karst related SOI's (Fig. 8); including karst terrain (16), sinkhole overflow (11) and cave (1). There is an overlap with the salt diapir SOI, which includes an additional three sinkholes and one cave SOI, as discussed later.

Single discharge measurements were quite variable, ranging from Meinzer Category 4 to 8, with the highest number of springs positioned in category $4(33 \%)$ followed by categories 5 and 7 (37\% combined). The variability is expected to be due, at least in part, to the extent of infilling of preglacial karst features with glacial debris such as till, diamicton and sand/gravel. The Category 4 springs ranged in single discharges from 875 to $2700 \mathrm{Lpm}$. One of the greatest discharges $(1690 \mathrm{Lpm})$ originated from a series of four linked sinkholes within the Washabuck solution trench at Rear Estemere (Fig. 8). Of the five monitored springs (Table 12) all can be classified as variable flow $(>100 \%)$, based upon the variability index.

Single temperature measurements were within the ambient range. Eight springs showed seasonal values, related to heating from exposed sinkhole ponds. One temperature logger at spring \#50 at the base of Marble Mountain, located within exposed marble karst terrain, exhibited seasonal conditions with a temperature range of 0 to $18^{\circ} \mathrm{C}$.

Instantaneous SC values indicated a wide variability, as expected given the range in rock types in which karst is developed. A total of $42 \%$ of springs associated with karst were hyperfresh, $27 \%$ fresh, $23 \%$ slightly saline and $8 \%$ moderately saline.

Twelve karst related springs had at least one water chemi$\mathrm{cal}$ analysis. Unlike the mixed water types found in the fault related springs, most karst related springs exhibited defined types. Limestones were associated with calcium-bicarbonate water type $(n=7)$, and gypsum evaporites were associated with calcium-sulfate $(n=2)$, sodium-sulfate $(n=1)$ and one sodium-chloride $(n=1)$ types. The one mixed type was a calcium/sodium-bicarbonate/chloride from a karst cave spring within the tidal zone. The $\mathrm{pH}$ values were neutral to moderately basic (6.2 to 8.3 ). None of the karst related springs exhibited precipitates at the outfall.

\section{Salt Diapir SOI}

The Cape Breton Island diapiric province is prominent along the west coast of the Island and offshore under the Gulf of St Lawrence. The diapirs were driven by downslope, gravitational compression during subsidence throughout the Carboniferous and therefore are not presently active. They consist of an Upper Windsor Group structural carapace overlying lower unexposed Windsor Group halite, interbedded with large thicknesses of shale, gypsum and carbonates. Three of the eleven salt diapirs present on the Island are near surface and exposed in wave cliffs at Mabou Mines, Port Hood Island and Broad Cove (Fig. 8), as noted by Baechler and Boehner (2014). The adjacent drag zones exhibit lithologies rotated into steeply dipping attitudes, resulting in significant folding, faulting and fracturing (Baechler 2015).

A total of six springs have been identified within the Mabou Mines and Broad Cove diapirs. These include one discharging from a karst cave within the central evaporite core, three seeping out of the wave cliff from the up-warped argillaceous, limestone flanks and three discharging as overflow out of three 10 to $80 \mathrm{~m}$ diameter, flooded sinkholes. Two of the active sinkholes are positioned in a valley floor directly over the Finlay Point diapir core, with Meinzer 5 discharges. The remainder, including the largest sinkhole, were in the Meinzer 7 to 8 category range. Given the wave cliff exposure 


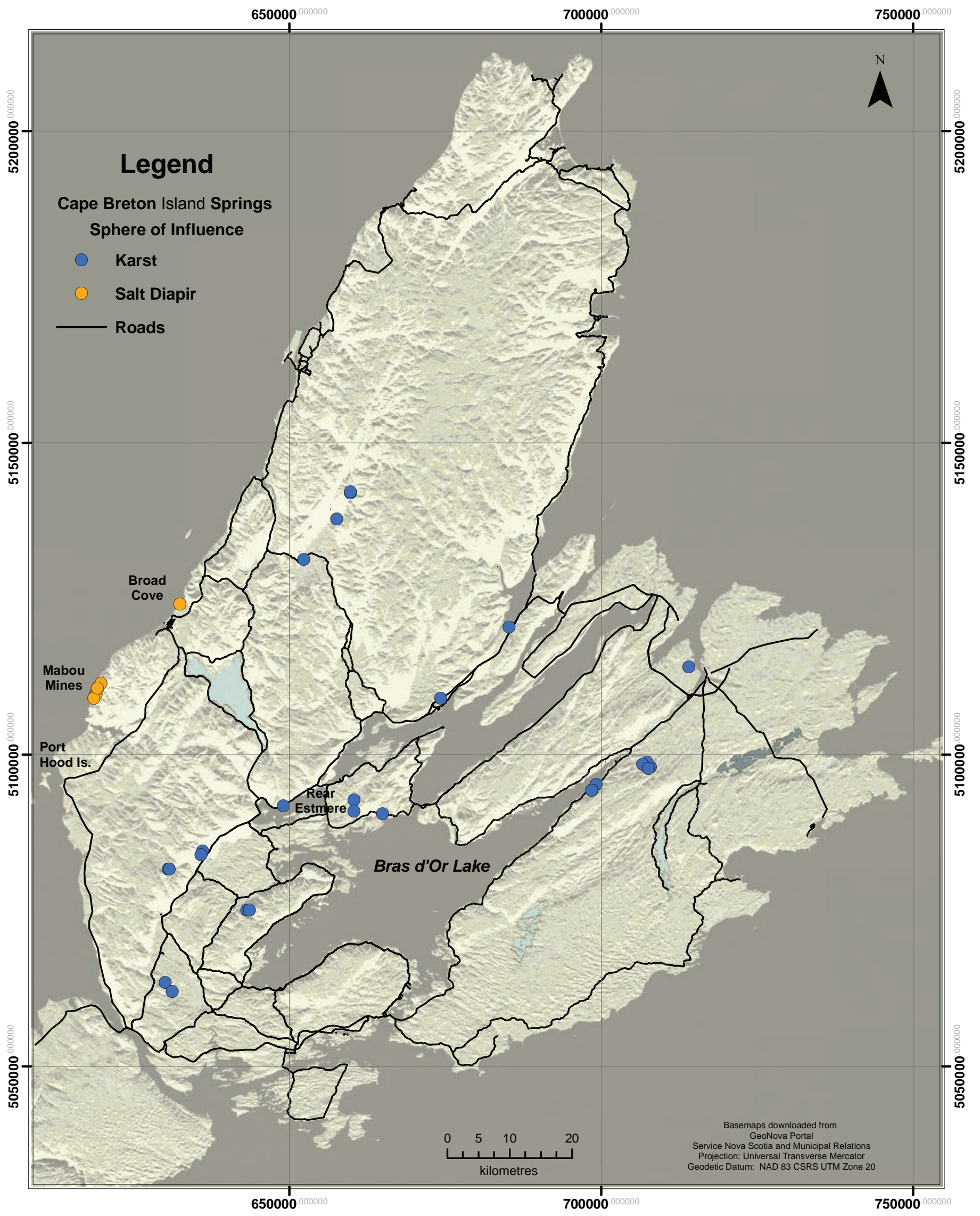

Figure 8. Location of springs related to Karst and Salt Diapir SOIs. 
Table 12. Discharge variability related to karst springs.

\begin{tabular}{cccccc}
\hline Location (Spring \#) & $\begin{array}{c}\text { No of } \\
\text { samples }\end{array}$ & $\begin{array}{c}\text { Monitoring } \\
\text { Period }\end{array}$ & $\begin{array}{c}\text { Maximum Flow } \\
\text { (Lpm) }\end{array}$ & $\begin{array}{c}\text { Minimum Flow } \\
\text { (Lpm) }\end{array}$ & $\begin{array}{c}\text { Variability } \\
\text { Index (\%) }\end{array}$ \\
\hline Glen Morrison (\#26) & 22 & 1993 to 2016 & 200 & 0.5 & 499 \\
Glen Morrison (\#28) & 12 & 1992 to 2014 & 535 & 115 & 158 \\
Marble Mtn (\#50) & 25 & 2002 to 2016 & 680 & 5 & 518 \\
Glen Morrison (\#57) & 75 & 1992 to 2016 & 5235 & 20 & 735 \\
Sugar Camp (\#60) & 8 & 1984 to 1986 & 3990 & 170 & 223 \\
\hline
\end{tabular}

NOTE: Variability as defined in Table 11.

and heating of sinkhole ponds the temperatures were predominately seasonal, except for ambient conditions from the karst cave.

The five springs where water was available for sampling gave SC values in the slightly saline range (1006 to $1800 \mathrm{uS} /$ $\mathrm{cm})$. The only exception was the largest sinkhole which was fresh $(229 \mathrm{uS} / \mathrm{cm})$, suggesting it is not hydraulically linked with the underlying diapir.

\section{Rockfall/Alluvial SOI}

Clow et al. (2003) and McClymont et al. (2011) noted that scree slopes can form groundwater reservoirs, providing contribution to streamflow through complicated flow paths. Grant (1994) observed that Cape Breton Island's landscape has been modified from exposure to proglacial, periglacial and paraglacial conditions, resulting in colluvial deposits that cover about $4 \%$ of the island. Rockfall (talus), landslide, avalanche, debris flow, creep and solifuction processes have created localized scree slopes along the steep margins of the Highlands within the Canyon and Mountain Flank hydrological regions. In localized areas these can interfinger with alluvial fans and elevated kame terraces. Combined these processes create the rockfall/alluvial SOI.

All scree slopes on the Island are below the present-day tree line and appear to be relict, vegetated landforms, except for the Grande Falaise in the Rigwash Valley (Fig. 9). In the Canyon region these deposits are now being eroded and redistributed down valley by adjacent rivers, which is evident in the Clyburn River canyon (Fig. 9). This process is referred to as the paraglacial cycle of sedimentation (Church and Slaymaker 1989). The discharge response of springs emanating from the base of scree slopes reflects rapid transmittal of water through layers of coarse debris common at the base and slower release from stratigraphically higher interbedded, finer-grained sediment layers (Clow et al. 2003).

A total of 20 springs (3.9\%) have been documented within the Rockfall/Alluvial SOI (Fig. 9) at New Campbelton along the northeastern flank of Kelly's Mountain, at Bucklaw along the eastern flank of Lewis Mountain, within the canyons of the Northeast Margaree, Clyburn, Grande Anse and North Aspy rivers, and in the Rigwash Valley along the northwestern flank of the Cape Breton Highlands. Additional springs may be associated with this SOI within the Hillslope steep SOI, however vegetated slopes make the underlying geology unknown. While the apex of the scree slopes is composed primarily of bedrock outcrop, the slopes may comprise a variety of underlying hydrostratigraphic units, including Structural HU, Igneous Plutonic and Volcanic/Metamorphic HUs, as well as a variety of glacial deposits such as Till HU, Sand/Gravel HU and Colluvium HU from multiple talus cones and alluvial fans.

Single discharge measurements ranged from Meinzer categories 5 to 8 , with most discharges classified as category 7. Two springs are category 4, both in the Rigwash Valley, which is also fault controlled. It is expected that some flow within this system infiltrates into underlying coarse, permeable glacial debris and therefore does not present itself as springs. Of the four monitored springs with sufficient data (Table 13) three exhibited variable discharge indices $(223 \%$ to $282 \%$ ) and one exhibited a subvariable index of $57 \%$.

Single measured temperatures were mostly ambient, with three springs showing seasonal temperatures. Hourly temperature data logger records at the Grande Anse site (\#185) monitored between July 2014 and April 2016 exhibited ambient temperatures ranging between $5.7^{\circ}$ and $6.8^{\circ} \mathrm{C}$. This spring exhibited no diurnal fluctuations, with delayed and at times unresponsive relationship to seasonal conditions, suggesting the influence of a deeper flow system. The Kiosk site (\#275), data logger records compiled between September 2015 and October 2016, exhibited a relatively constant temperature range between $6.8^{\circ}$ and $7.3^{\circ} \mathrm{C}$. In contrast the outflow from the spring fed Melanie Pond (\#281) monitored between February and October 2016, exhibited a seasonal temperature range from $0^{\circ}$ to $25^{\circ} \mathrm{C}$, due to heating in the shallow upgradient pond, which was never ice covered.

Specific conductance values were available for 20 springs; of which 12 were hyperfresh and 8 were fresh. Four had water chemical analyses showing a hyperfresh to fresh (TDS 67 to $150 \mathrm{mg} / \mathrm{L}$ ), soft to moderately soft (hardness as $\mathrm{CaCO}_{3}$ ranging from 41 to $65 \mathrm{mg} / \mathrm{L}$ ), corrosive, calcium-bicarbonate to calcium-chloride/bicarbonate type water, with a neutral to moderately basic $\mathrm{pH}$ of 7.6 to 8.0. None of the springs exhibited precipitate at their outfalls. 


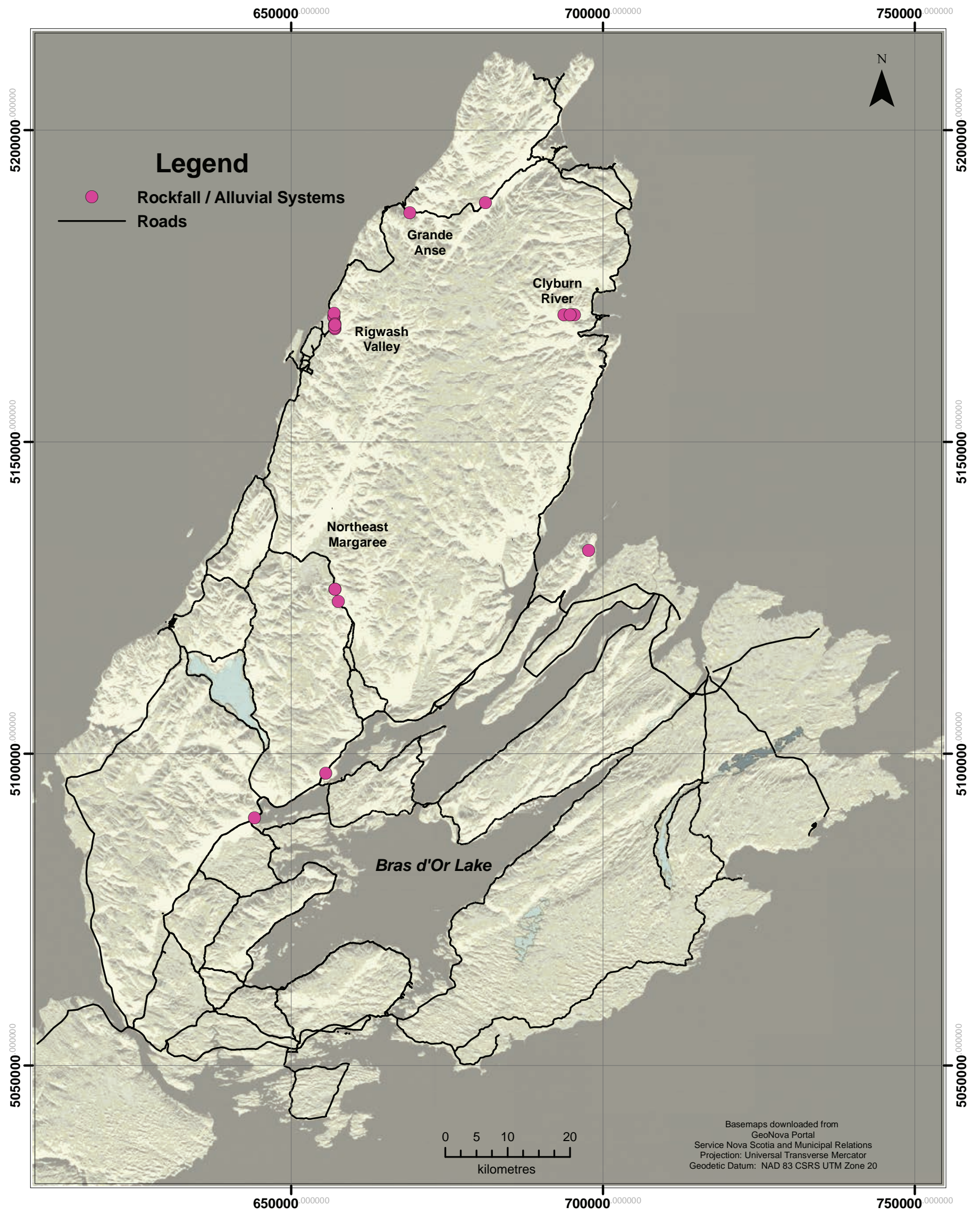

Figure 9. Location of springs related to Rockfall/Alluvial SOIs. 
Table 13. Discharge variability related to Rockfall/Alluvial springs.

\begin{tabular}{cccccc}
\hline Location (Spring \#) & No of & Period & $\begin{array}{c}\text { Maximum Flow } \\
\text { (Lpm) }\end{array}$ & $\begin{array}{c}\text { Minimum Flow } \\
\text { (Lpm) }\end{array}$ & $\begin{array}{c}\text { Variability } \\
\text { Index (\%) }\end{array}$ \\
\hline Grande Anse (\#185) & 8 & June 2014 to May 2017 & 810 & 23 & 282 \\
Bucklaw (\#119) & 11 & June 1999 to May 2017 & 431 & 246 & 57 \\
Kiosk Rigwash Valley (\#275) & 15 & October 2015 to April 2017 & 1450 & 258 & 320 \\
Melanie Pond Rigwash Valley (\#281) & 14 & October 2015 to April 2017 & 5750 & 223 \\
\hline
\end{tabular}

NOTE: Variability as defined in Table 11.

\section{Debris Avalanche SOI}

One of the regions identified in Canada as susceptible to landslide hazard are the deep gorges and canyons within the Cape Breton Highlands (Evans et al. 2005). Although a variety of landslide morphologies exist, thin-skinned debris flows dominate recent mass wasting processes in the Highlands (Wahl et al. 2007). Such debris flows resulting from springs have been reported from a wide range of mountainous environments (Van Steijn 1996; Otton and Hilleary 1985; French 2007).

Finck (1993) and Wahl et al. (2007) investigated 88 thinskinned, debris avalanche events within canyons and gorges incised into the Cape Breton Highlands. They reported that the avalanche sites were typically long and narrow, commonly initiated just below the intersection of the valley wall and highland peneplain, had no association with large-scale surface depressions and were shallow, removing no more than $1.5 \mathrm{~m}$ of the surface. The point of failure was primarily where groundwater discharged as springs between: (1) weathered material and underlying more competent bedrock, (2) low permeable lodgement till overlain by highly permeable colluvium, and/or (3) impermeable weathered bedrock saprolite overlain by permeable colluvium. Fourteen sites exhibited debris discharge into rivers below, which at select sites created debris dams across rivers up to $38 \mathrm{~m}$ in width (Finck 1993).

Of the initial 88 sites identified with debris avalanches, a total of 32 were located based on the presence of active, non-vegetated scars on recent (2011 to 2016) Google Earth satellite images. An additional 36 sites were identified using the same approach throughout highland areas over Cape Breton Island (Fig. 7). All were associated with deeply incised, "V"-shaped canyons and gorges. The avalanche initiation sites were predominately at the peneplain - steep slope transition, with $75 \%$ located at elevations exceeding $300 \mathrm{~m}$. Most sites occurred on steep slopes with 86\% exceeding 50\% slope and $31 \%$ exceeding $75 \%$ slope.

\section{SPRING MONITORING}

The provincial groundwater observation well monitoring program does not include springs at present. Three temporal trends can be used to characterize spring discharge (Manga 1999), including: (1) long term trends, (2) time lag between recharge and peak discharge, and (3) mean residence time. The Cape Breton Island dataset only allows for discussion of long-term trends.

A spring monitoring program was established and is now being operated by the authors from the above dataset starting in 2016. Of the 510 springs identified to date 27 were selected (Fig. 10) for monitoring, with details summarized in Table 14.

The selection of monitoring sites was based upon springs with relatively natural catchments, which provided areal coverage of the Island, through all hydrological regions. Where possible sites were selected with long-term records. The minimum frequency for sampling is established at twice per year to characterize the maximum (spring/fall recharge) and minimum (late summer recession) envelope which can be used to detect long-term trends related to changing climate.

Specific conductance, temperature, and flow rate for one of the long-term stations is provided in Figure 11. Spring \#57 has been monitored at a monthly frequency for 25 years and represents a karst spring in the Lowland region. Temperatures exhibit seasonal fluctuations with an ambient range of $5^{\circ}$ to $10^{\circ} \mathrm{C}$. Specific conductance remains stable ranging from 139 to $335 \mathrm{uS} / \mathrm{cm}$. Flow rates vary seasonally, ranging from 20 to $5230 \mathrm{Lpm}$.

A Mann-Kendall trend test was carried out on the field parameters from Spring \#57 using USEPA's ProUCL 5.1. Software and documentation were downloaded November 24, 2018 from https://www.epa.gov/land-research/proucl-software. The results indicated that there was insufficient evidence to identify a significant trend at the specified level of significance $($ alpha $=0.05)$ for the parameters shown.

\section{MANAGEMENT ISSUES}

Numerous authors have noted the need for research and monitoring of springs as part of an overall groundwater/ surface water management program (Rivard et al. 2014; Nichols et al. 2014; Finck 1993; Hinton 2014). To support effective provincial water resources management and permitting, interdisciplinary spring research should focus on: 


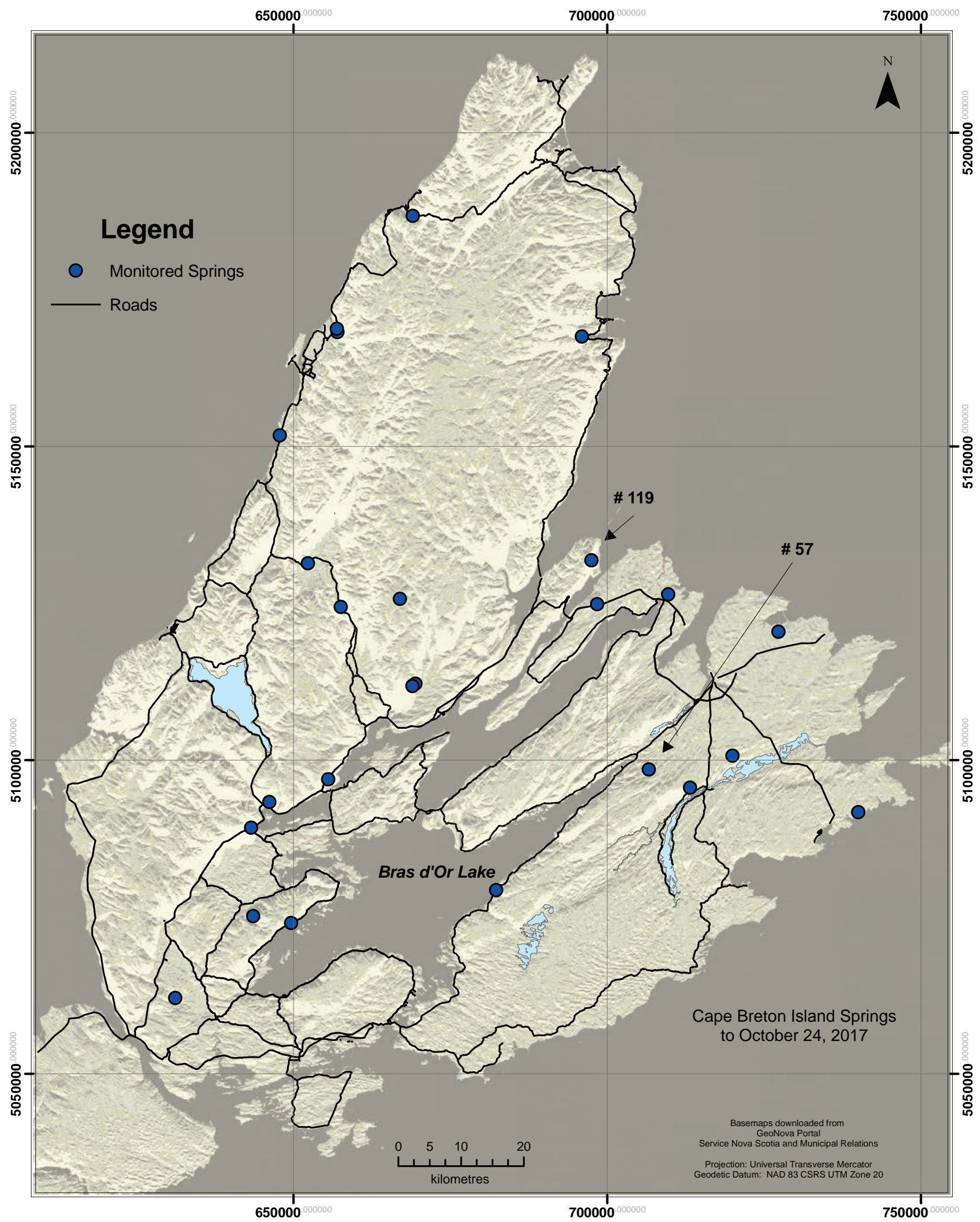

Figure 10. Location of springs under active monitoring. 
Table 14. Cape Breton Island spring monitoring program.

\begin{tabular}{|c|c|c|c|c|c|c|}
\hline $\begin{array}{l}\text { Location } \\
(\text { Spring \#) }\end{array}$ & Region & $\begin{array}{l}\text { Sphere of } \\
\text { Influence }\end{array}$ & Q & Temperature & $\begin{array}{c}\text { Hydrostratigraphic } \\
\text { Unit }\end{array}$ & Period (n) \\
\hline Rear Baddeck (\# 224) & Mountain Flank & Fault & 3 & Ambient & Structural & 2015-2017 (6) \\
\hline Rear Baddeck (\#55) & Mountain Flank & Fault & 4 & Ambient & Structural & 2012-2017 (10) \\
\hline Rear Baddeck (\#358) & Mountain Flank & Fault & 6 & Ambient & Structural & 2014-2017 (9) \\
\hline Rear Baddeck (\#307) & Mountain Flank & Fault & 4 & Ambient (DLT) & Structural & 2016-2017 (5) \\
\hline Glen Morrison (\#57) & Lowland & Karst Terrain & 7 & Ambient & Karst & 1992-2017 (180) \\
\hline Grande Anse (\#185) & Canyon & Rockfall Alluvial & 5 & Ambient (DLT) & Colluvium & 2014-2017 (8) \\
\hline Big Barren (\#145) & Highland & Helocrene & 5 & Seasonal & Organic & 2013-2017 (9) \\
\hline Lake O'Law (\#95) & Canyon & Rockfall Alluvial & 6 & Ambient & Colluvium & 1999-2017 (6) \\
\hline Marble Mtn (\#46) & Mountain Flank & Fault & 5 & Ambient (DLT) & Structural & 2012-2017 (4) \\
\hline Rigwash Valley (\#275) & Mountain Flank & Fault & 4 & Ambient (DLT) & Colluvium & 2015-2017 (16) \\
\hline Sugar Camp (\#297) & Lowland & Reclaimed Mine & 4 & Seasonal & Karst & 2016-2017 (17) \\
\hline Rigwash Valley (\#281) & Mountain Flank & Limnocrene & $4(\mathrm{DLH})$ & Seasonal (DLT) & Colluvium & 2015-2017 (14) \\
\hline Bucklaw (\#119) & Mountain Flank & Rockfall Alluvial & 5 & Ambient & Colluvium & 1999-2017 (12) \\
\hline Dalem Lake (\#359) & Lowland & Limnocrene & 4 & Seasonal & Cumberland & 2010-2017 (4) \\
\hline Irishvale (\#32) & Mountain Flank & Hillslope Steep & 5 & Ambient & Vol./Met. & 2012-2017 (7) \\
\hline Caribou Marsh (\#84) & Lowland & Hillslope Shallow & 6 & Ambient & Cumberland & 1999-2017 (5) \\
\hline Mineral Rock (\#92) & Mountain Flank & Hillslope Shallow & 6 & Ambient & Horton & 1999-2017 (5) \\
\hline Wild Cove (\#253) & Atlantic Coastal & Helocrene & 6 & Seasonal & Organic & 2015-2017 (5) \\
\hline NE Margaree (\#280) & Canyon & Karst sinkhole & 4 & Seasonal & Karst & 2015-2017 (6) \\
\hline Dominion (\#282) & Lowland & Mine Pool & 5 & Ambient & Coal Mine Pool & 2012-2017 (55) \\
\hline Florence (\#283) & Lowland & Mine Pool & 5 & Ambient & Coal Mine Pool & 2010-2017 (85) \\
\hline Cap Le Moine (\#354) & Lowland & Wave Cliff & 6 & Seasonal & Cumberland & 2016-2017 (6) \\
\hline Whycocomagh (\#45) & Mountain Flank & Rheocrene & 5 & Ambient & Horton & 2010-2017 (4) \\
\hline Marble Mtn (\#50) & Highland & Karst Terrain & 6 & Ambient & Karst & 2002-2017 (27) \\
\hline Ingonish Hbr. (\#158) & Canyon & Overflow well & 5 & Ambient & Sand/Gravel & 2001-2017 (54) \\
\hline Cape Dauphin (\#76) & Mountain Flank & Fault & 5 & Ambient & Structural & 1987-2017 (29) \\
\hline Iron Mines (\#96) & Mountain Flank & Fault & 4 & Ambient & Structural & 1999-2017 (3) \\
\hline
\end{tabular}

NOTES: Region - Hydrological region; Q - Meinzer discharge Category; Period - time interval for sampling; n - number of samples; DLH - data logger of head levels available for select periods; DLT - data logger temperature data available for select periods.

(1) Identification and characterization of additional springs: This should include both terrestrial, as well as submarine springs in the nearshore coastal environment. Investigations of groundwater dependent ecosystems associated with springs should also be a focus. Priority should be given to springs associated with areas of enhanced land use, exist-ing large groundwater withdrawals and important aquatic ecosystems. (2) Changing Climate: Select springs should be instrumented to allow for enhanced monitoring frequency of discharge, temperature, and select chemical parameters to better evaluate long term change and to provide an early warning system for impacts associated with changing climate. (3) Integrated Monitoring: The provincial groundwater observation well monitoring program should be integrated and enhanced with springs within select hydrological regions and SOIs.

\section{CONCLUSIONS}

Cape Breton Island provides a hydrogeological view into a tectonically ancient, exhumed, glaciated, deglaciated, now tectonically inactive, deep crustal terrain. Identification of 510 springs has indicated 19 spheres of influence, spread out over seven hydrological regions.

There is a wide variability in discharge from Meinzer category 8 to 3; no large magnitude category 1 or 2 springs have been identified to date. The larger flows were related to faults and karst, followed by rockfall/alluvial systems, primarily in the Mountain Flank Region. Total dissolved solids were highly variable in both concentration (ranging from 38 to $73,000 \mathrm{mg} / \mathrm{L}$ ) and spatial distribution. The springs exhibited predominately hyperfresh to fresh water; with the Lowland and Mountain Flank regions exhibiting the more saline 


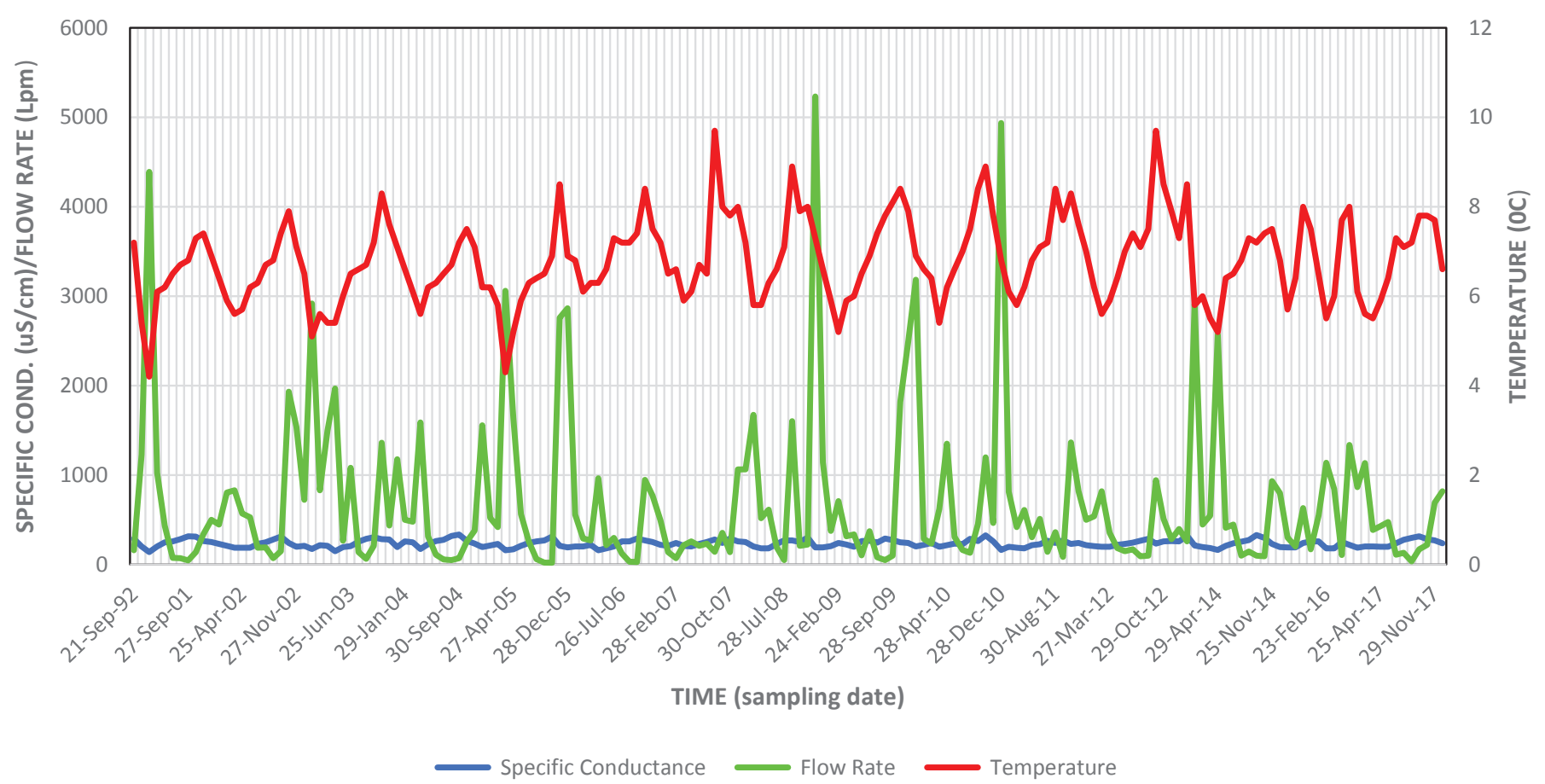

Figure 11. Trends in specific conductance, temperature and flow rate at Spring \#57.

springs. The $\mathrm{pH}$ ranged primarily from neutral to moderately basic, with alkaline conditions associated with limestones, and acid conditions associated with coal mine pools, reclaimed coal strip mines and wetlands. Temperatures were predominantly ambient to seasonal, with no warm or hot springs encountered.

Fault-controlled springs comprised approximately 20\% of the data set. Five sites encompassed numerous, closelyspaced springs, termed spring fields. They comprised most of the Category 4 springs and the only Category 3 spring; flow regimes were predominantly variable.

Karst-controlled springs comprised approximately 6\% of the data set. Spot discharges were variable, ranging from Meinzer categories 4 to 8 , and exhibited predominately variable flow regimes. The variability is expected to be due, at least in part, to the extent of infilling of pre-glacial karst features with glacial debris.

Three of the eleven salt diapirs present on the Island are near surface and exposed in wave cliffs, where six springs were identified; either discharging out of the cliffs, or as overflows from flooded sinkholes. These springs exhibited predominantly seasonal temperatures with generally slightly saline chemistry.

Rockfall/Alluvial controlled springs comprised approximately $4 \%$ of the data set. Spot discharges ranged from Meinzer categories 5 to 8 , with a predominantly variable flow regime. It is expected that some flow within this system infiltrates into underlying permeable deposits and therefore does not present itself as springs.

A total of 68 sites documented springs creating thinskinned debris flows. All were associated with deeply incised, "V"-shaped canyons and gorges.
Twenty-seven springs were selected for an ongoing monitoring program. The springs with longer term data do not suggest changes in response to changing climate.

All data has been provided to the Nova Scotia Department of Energy and Mines for inclusion in their water resources database; to be made public at their discretion.

Future research is required to: (1) identify and characterize these springs in select high priority areas, (2) identify the groundwater dependent ecosystems associated with the springs, and (3) instrument selected springs to aid in identifying impacts associated with changing climate.

\section{ACKNOWLEDGEMENTS}

The paper was significantly improved by comments received through numerous discussions with and responding to constructive criticism from anonymous reviewers and the editor. The authors would like to gratefully acknowledge and thank all those that assisted in this endeavor. Mr. Bill Jones is greatly acknowledged for developing the associated GIS database, which facilitated the analysis.

\section{REFERENCES}

Alberta Geological Survey. 2017. Springs inventory. URL $<$ http://ags.aer.ca/springs-inventory.htm>, 26 March 2018.

Alfaro, C. and Wallace, M. 1994. Origin and classification of springs and historical review with current applications. Environmental Geology, 24, pp. 112-124. https://doi. org/10.1007/bf00767884 
Alley, W.M. and Alley, R. 2017. High and Dry: meeting the challenges of the world's growing dependence on groundwater. Yale University Press, New Haven and London.294 p. https://doi.org/10.12987/yale/9780300220384.001.0001

Asjarvi, J., Marttila, H. Rossi, P.M., Ala-aho, P., Olofsson, B., Nisell, J., Backman, B., Monen, J. Virtanen, R., Paasivirta, L., Britschgi, R., Klove B., and Muotka, T. 2015. Climate-induced warming imposes a threat to north European spring ecosystems. Global Change Biology, 21, pp. 4561-4569. https://doi.org/10.1111/gcb.13067

Baechler, F. 2014. Cape Breton's changing climate: implications for its fresh water resources. International Association of Hydrogeologists, Canadian National Chapter, Atlantic Region webinar series. URL < www.gwinsight.com/ webinars>, 26 March 2018.

Baechler, F. 2015. The geology and hydrogeology of faults on Cape Breton Island, Nova Scotia, Canada: an overview. Atlantic Geology, 51, pp. 242-268. https://doi. org/10.4138/atlgeol.2015.010

Baechler, F. 2017. The geology and hydrogeology of buried bedrock valley aquifers on Cape Breton Island, Nova Scotia: an overview. Atlantic Geology, 53, pp. 301-324. https://doi.org/10.4138/atlgeol.2017.013

Baechler, F. and Baechler, L. 2009. Mapping Cape Breton's Waterscape - Approach and Challenges. In International Association of Hydrogeologists, Canadian National Chapter GeoHalifax Conference September 2009. pp. 1222-1228.

Baechler F. and R. Boehner. 2014. Geology and Hydrogeology of karst in Cape Breton: an overview. Canadian Journal of Earth Sciences, 51, pp. 1-14. https://doi.org/10.1139/ cjes-2013-0157

Bakalowicz, M., El-Hajj, A., El Hakim, M., Al Charideh, A.R., Al-Fares, W., Kattaa, B., Fleury, P., Brunet, P., Dörfliger, N., Seidel, J.L., and Najem, W. 2007. Hydrogeological settings of karst submarine springs and aquifers of the Levantine coast (Syria, Lebanon). Towards their sustainable exploitation. In TIAC 07. International symposium on technology of seawater intrusion into coastal aquifers at Almeria, Spain, volume 1, pp. 721-732.

Baker, V.R., Kochel, R.C., Laity, J.R., and Howard, A.D. 1990. Spring sapping and valley network development. Geological Society of America Special Paper 252, pp. 235-265. https://doi.org/10.1130/spe252-p235

Borneuf, D. 1983. Springs of Alberta. Alberta Research Council Earth Sciences Report 82-3, 105 p.

Brunke, M. and Gonser, T. 1997. The ecological significance of exchange processes between rivers and groundwater. Freshwater Biology, 37, pp. 1-33. https://doi.org/10.1046/ j.1365-2427.1997.00143.x

Buczynski, S. and Rzonca, B. 2011. Effects of crystalline massif tectonics on groundwater origin and catchment size of a large spring area in Zieleniec, Sudety Mountains, southwestern Poland. Hydrogeology Journal, 19, pp. 1085-1101. https://doi.org/10.1007/s10040-011-0732-3

Cantonati, M., Komarek J., and Montejano, G. 2015. Cyanobacteria in ambient springs. Biodiversity and Conser- vation, 24, pp. 865-888. https://doi.org/10.1007/s10531015-0884-X

Cantonati, M., Seadelli, S., Ogata, K., Tran, H., Sanders, D., Gerecke, R., Rott, E., Filippini, M., Gargini, A., and Celico. F. 2016. A global review on ambient limestone-precipitating springs (LPS): Hydrogeological setting, ecology and conservation. Science of the Total Environment. 568, pp. 624-637. https://doi.org/10.1016/j.scitotenv.2016.02.105

Caron, M.E., Grasby, S.E., and Ryan, M.C. 2008. Spring water trace element geochemistry: A tool for resource assessment and reconnaissance mineral exploration. Applied Geochemistry, 23, pp. 3561-3578. https://doi. org/10.1016/j.apgeochem.2008.07.020

Church, M. and Slaymaker, O. 1989. Disequilibrium of Holocene sediment yield in glaciated British Columbia. Nature, 337 (2), pp. 452-454. https://doi.org/10.1038/337452a0

Clow, D.W., Schrott, L., Webb, R., Campbell, D.H., Torizzo, A., and Dornblaser. M. 2003. Groundwater occurrence and contributions to streamflow in an Alpine catchment, Colorado Front Range. Ground Water, 41 (7), pp. 937950. https://doi.org/10.1111/j.1745-6584.2003.tb02436.x

Cross, H.J. and Goyette, R.J. 2000. Hydrogeological Evaluation Springs of Nova Scotia, self-published by Heather Cross, Dartmouth Nova Scotia, 166 p. Out of print, available for viewing at Nova Scotia Department of Natural Resources library, Halifax, Nova Scotia, call numbers: 551.498 C951 and C952.

Curewitz, D. and Karson, J. A. 1997. Structural settings of hydrothermal outflow: fracture permeability maintained by fault propagation and interaction. Journal of Volcanology and Geothermal Research, 79, pp. 149-168. https:// doi.org/10.1016/s0377-0273(97)00027-9

Davis S.D. and DeWiest, R.J.M. 1966. Hydrogeology. John Wiley and Sons Inc. New York. 463 p.

Dimova, N.T., Burnett W.C., and Speer, K. 2011. A natural tracer investigation of the hydrological regime of Spring Creek Springs, the largest submarine spring system in Florida. Continental Shelf Research, 31, pp. 731-738. https://doi.org/10.1016/j.csr.2011.01.010

Drury, M.J., Jessop, A.M., and Lewis, T.J. 1987. The thermal nature of the Canadian Appalachian crust. Tectonophysics, 133, pp. 1-14. https://doi.org/10.1016/00401951(87)90276-9

Evans, S.G., Cruden, D.M., Bobrowsky, P.T., Guthrie, R.H., Keegan, T.R., Liverman, D.G.E., and Perret, D. 2005. Landslide risk assessment in Canada; a review of recent developments. In Landslide Risk Management, Proceedings of the International Conference on Landslide Risk Management. Edited by O. Hungr, R. Fell, R. Couture and E. Eberhardt. Taylor and Francis Group, London, pp. 351-363. https://doi.org/10.1201/9781439833711

Faure, H., Walter, R.C., and Grant, D.R. 2002. The coastal oasis: ice age springs on emerged continental shelves. Global and Planetary Change, 33, pp. 47-56. https://doi. org/10.1016/s0921-8181(02)00060-7

Ferguson, G. and Grasby S.E. 2011. Thermal springs and heat flow in North America. Geofluids, 11, pp. 294-301. 
https://doi.org/10.1111/j.1468-8123.2011.00339.x

Finck, P.W. 1993. An evaluation of debris avalanches in the central Cape Breton Highlands, Nova Scotia. Nova Scotia Department of Natural Resources, Mines and Energy Branch, Paper ME 1993-01, 68 p, 16 maps.

Fleury, P., Bakalowicz, M., and de Marsily, G. 2007. Submarine springs and coastal karst aquifers: a review. Journal of Hydrology, 339 (1), pp. 79-92. https://doi.org/10.1016/j. jhydrol.2007.03.009

Florea, L.J. and Vacher, H.L. 2006. Spring flow hydrographs: eogenetic vs teleogenetic karst. Ground Water, 44 (3), pp. 352-361. https://doi.org/10.1111/j.17456584.2005.00158.x

French, H.M. 2007. The Periglacial Environment. John Wiley and Sons Ltd, England. 450 p.

Grant, D.R. 1994. Quaternary Geology, Cape Breton Island, Nova Scotia. Geological Survey of Canada Bulletin 482, 159 p. https://doi.org/10.4095/194812

Grasby, S.E. and Hutcheon, I. 2001. Controls on the distribution of thermal springs in the southern Canadian Cordillera. Canadian Journal of Earth Sciences. 38, pp. 427-440. https://doi.org/10.1139/e00-091

Grasby, S.E. and Lepitzki, D.A.W. 2002. Physical and chemical properties of the Sulphur Mountain thermal springs, Banff National Park, and implications for endangered snails. Canadian Journal of Earth Sciences, 39, pp. 13491361. https://doi.org/10.1139/e02-056

Grasby, S.E., Majorowicz, J., and Ko, M. 2009. Geothermal Maps of Canada. Geological Survey of Canada Open File 6167, 35 p. https://doi.org/10.4095/247765

Hem, J.D. 1985. Study and Interpretation of the chemical characteristics of natural water, 3rd Edition. U.S. Geological Survey Water-Supply Paper 2254, 263 p.

Hilberg, S. and Kreuzer, M. 2013. Identification of a deep flow system in a dolomitic alpine aquifer - case study Wimmerbauern spring, Bad Ischl. Austrian Journal of Earth Sciences, 106 (1), pp. 16-25.

Hinton, M.J. 2014. Groundwater-surface water interactions in Canada. In Canada's Groundwater Resources. Edited by A. Rivera. published by Fitzhenry and Whiteside, Markham Ontario, pp. 152-185.

Klove, B., Ala-Aho, P., Bertrand, G., Gurdak, J.J., Kupfersberger, H., Kvaerner, J., Muotka, T., Mykra, J., Preda, E., Rossi, P., Bertacchi Uvo, C., Velasco, E., and Pulido-Velazquez. M. 2013. Climate change impacts on groundwater and dependent ecosystems. Journal of Hydrology, 518, Part B, pp.250-266. https://doi. org/10.1016/j.jhydrol.2013.06.037

Larsen, L.G., Chol, J., Nungesser, M.K. and Harvey, J.W. 2012. Directional connectivity in hydrology and ecology. Ecological Applications, 22 (8), pp. 2204-2220. https:// doi.org/10.1890/11-1948.1

Manga, M. 1999. On the timescales characterizing groundwater discharge at springs. Journal of Hydrology, 219, pp. 56-69. https://doi.org/10.1016/s0022-1694(99)00044-x

McClymont, A. F., Roy, J.W., Hayashi, M., Bentley, L.R., Maurer, J., and Langston, G. 2011. Investigating ground- water flow paths within proglacial moraine using multiple geophysical methods. Journal of Hydrology, 399, pp. 57-69. https://doi.org/10.1016/j.jhydrol.2010.12.036

McMahon, P., Short, G., and Walker, D. 1986. Petroleum wells and drill holes with petroleum significance onshore Nova Scotia. Nova Scotia Department Mines and Energy, Information Series No 10, $194 \mathrm{p}$.

Meinzer, O.E. 1923. Outline of Ground-Water Hydrology with Definitions. U.S. Geological Survey Water-Supply Paper 494, 75 p.

Nash, D.J. 1996. Groundwater sapping and valley development in the Hackness Hills, North Yorkshire, England. Earth Surface Processes and Landforms, 21, pp. 781-795. https://doi.org/10.1002/(sici)10969837(199609)21:9<781::aid-esp616>3.0.c0;2-o

Neily, P.D., Quigley, E., Benjamin, L., Stewart, B., and Duke, T. 2017. Ecological Land Classification for Nova Scotia, Nova Scotia Department of Natural Resources, Renewable Resources Branch. DNR 2017-13. 298 p.

Nichols, A.L, Willis, A.D., Jeffres, C.A., and Deas, M.L. 2014. Water temperature patterns below large groundwater springs: management implications for Coho salmon in the Shasta River, California. River Research and Applications, 30, pp. 442-455. https://doi.org/10.1002/rra.2655

Nova Scotia Museum. 1997. Natural History of Nova Scotia, Vol. I, Topics and Habitats. Co-published by Province of Nova Scotia and Nimbus Publishing, 304 p.

Otton, E.G. and Hilleary, J.T. 1985. Maryland springs - their physical, thermal, and chemical characteristics. Maryland Geological Survey Report of Investigations, No. 42, 49 p.

Pascucci, V., Gibling, M.R., and Williamson, M.A., 2000. Late Paleozoic to Cenozoic history of the offshore Sydney Basin, Atlantic Canada. Canadian Journal of Earth Sciences. 37, pp. 1143-1165. https://doi.org/10.1139/e00$\underline{028}$

Pentecost, A., Jones, B., and Renaut, R.W. 2003. What is a hot spring? Canadian Journal of Earth Sciences. 40, pp. 1443-1446. https://doi.org/10.1139/e03-083

Perez, E.S. 2001. Distribution functions of spring discharges according to their lithologies and the influence of lower limit to flow: an example from Spain. Ground Water, 39 (2), pp. 203-209. https://doi.org/10.1111/j.1745-6584.2001. tb02301.x

Renaut, R.W. and Jones, B. 2003. Sedimentology of hot springs systems. Canadian Journal of Earth Sciences, 40, pp. 1439-1442.

Rivard, C., Parent, M., Lavoie, D., Cousineau. P. MacQuarrie, K.T.B., Somers, G., Lamontagne, C., Drage, J., and Daigle, A. 2014. Chapter 14 Appalachians. In Canada's Groundwater Resources. Edited by A. Rivera. Fitzhenry and Whiteside, Markham Ontario, pp. 540-595. https:// doi.org/10.4095/296949

Sada, D.W. and Pohlmann, K.F. 2002. Spring inventory and monitoring protocols. In Conference Proceedings Springfed wetlands: important scientific and cultural resources of the Intermountain Region. URL <https://www.dri.edu/ images/stories/conferences and workshops/spring-fed- 
wetlands/spring-fed-wetlands-sada-pohlmann-protocol. pdf >, 27 March 2018.

Sanders, D., Wertl, W., and Rott, E. 2010. Spring-associated limestones of the Eastern Alps: overview of facies, deposystems, minerals, and biota. Facies. 57 (3), pp. 395-416. https://doi.org/10.1007/s10347-010-0252-y

Sharpe, D.R., Russell H.A.J., Dyke, L., Grasby, S.E., Gleeson, T., Michaud, Y., Savard, M.M., Wei, M., and Wozniak, P.R.J. 2014. Chapter 8 Hydrogeological Regions of Canada. In Canada's Groundwater Resources. Edited by A. Rivera, published by Fitzhenry and Whiteside, Markham Ontario, pp. 264-299. https://doi.org/10.4095/296943

Springer, A.E. and Stevens, L.E. 2009. Spheres of discharge of springs. Hydrogeology Journal, 17, pp. 83-93.

Springer, A.E., Stevens, L.E., Ledbetter, J.D., Schaller, E.M., Gill, K.M., and Rood, S.B. 2015 Ecohydrology and stewardship of Alberta springs ecosystems. Ecohydrology, 8, pp. 896-910. https://doi.org/10.1002/eco.1596

Stevens, L.E., Springer, A.E., and Ledbetter, J.D. 2011. Inventory and monitoring protocols for springs ecosystems. Version: 1 June 2011. URL < http://www.springstewardship.org/PDF/Springs Inventory Protocols 110602. pdf>, 14 April 2018.

Taniguchi, M., Burnett, W.C., Cable, J.E., and Turner, J.V. 2002. Investigation of submarine groundwater discharge.
Hydrological Processes, 16, pp. 2115-2129. https://doi. org/10.1002/hyp.1145

Thornthwaite, C. 1948. An approach towards a rational classification of climate. Geographical Review, 38 (1). pp. 55-94.

Van Everdingen, R.O. 1972. Thermal and mineral springs in the Southern Rocky Mountains of Canada. Environment Canada, Water Management Service, 145 p.

van Staal, C.R. and Barr, S.M. 2012. Lithospheric architecture and tectonic evolution of the Canadian Appalachians. In Tectonic Styles in Canada Revisited: the LITHOPROBE perspective. Edited by J.A. Percival, F.A. Cook, and R.M. Clowes. Geological Association of Canada Special Paper 49, pp. 41-95.

Van Steijn, H. 1996. Debris-flow magnitude-frequency relationships for mountainous regions of Central and Northwest Europe. Geomorphology, 15. pp. 259-273. https:// doi.org/10.1016/0169-555x(95)00074-f

Wahl, K., Spooner, I., and Colville, D. 2007. Thin-skinned debris flows in Cape Breton Highlands National Park, Nova Scotia, Canada. Atlantic Geology, 43, pp. 45-56. https://doi.org/10.4138/4213

Editorial responsibility: Denise Brushett 